FERNANDA RESENDE DJAHJAH 

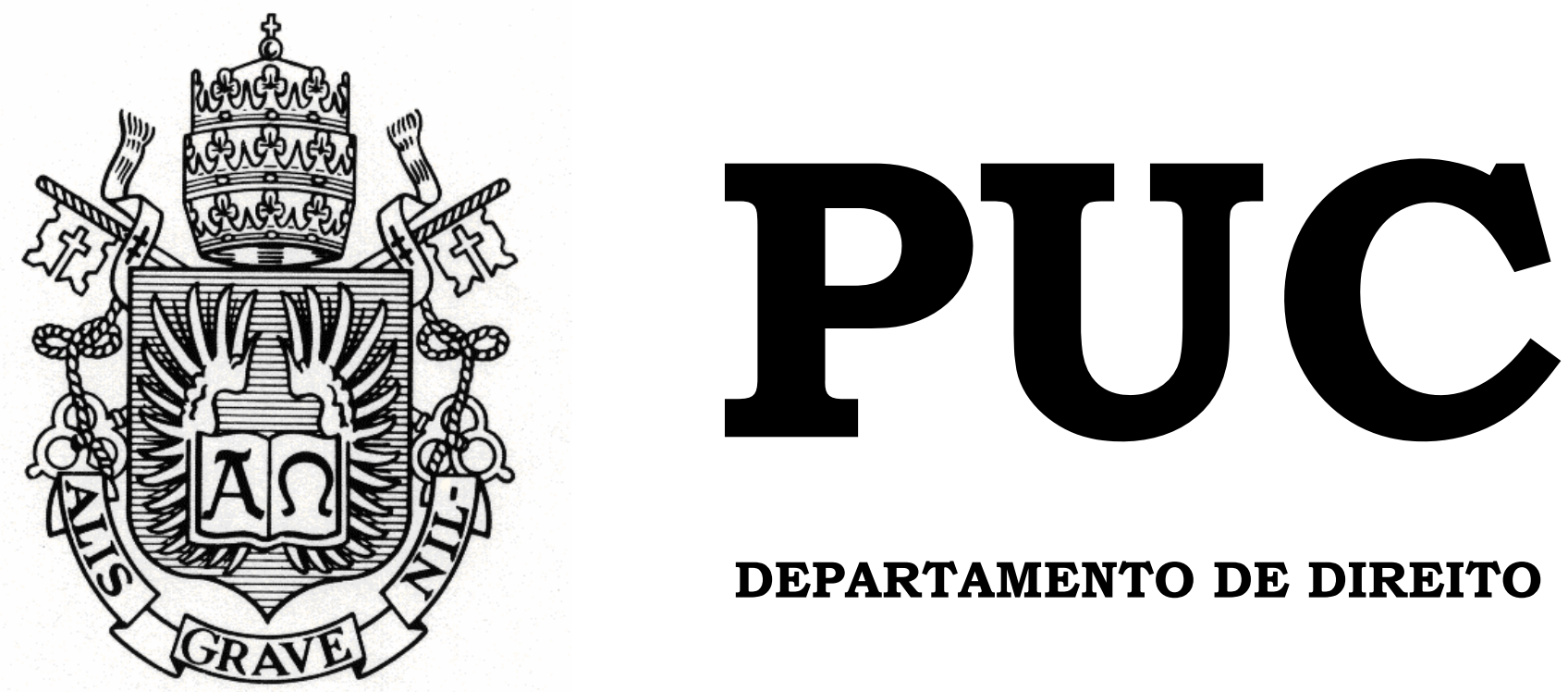

DEPARTAMENTO DE DIREITO

\section{CRÍTICA AO CRIME DE EMBRIAGUEZ AO VOLANTE À LUZ DA “ADMINISTRATIVIZAÇÃO” DO DIREITO PENAL E DA GARANTIA CONTRA A AUTO-INCRIMINAÇÃO}

por

FERNANDA RESENDE DJAHJAH

ORIENTADOR: PROF. PAULO FREITAS RIBEIRO CO-ORIENTADOR: PROF. DIOGO MALAN

2010.1

PONTIFÍCIA UNIVERSIDADE CATÓLICA DO RIO DE JANEIRO RUA MARQUÊS DE SÃO VICENTE, 225 - CEP 22453-900 RIO DE JANEIRO - BRASIL 


\title{
CRÍTICA AO CRIME DE EMBRIAGUEZ AO VOLANTE À LUZ DA “ADMINISTRATIVIZAÇÃO” DO DIREITO PENAL E DA GARANTIA CONTRA A AUTO-INCRIMINAÇÃO
}

\author{
por \\ FERNANDA RESENDE DJAHJAH
}

Monografia apresentada ao Departamento de Direito da Pontificia Universidade Católica do Rio de Janeiro (PUC-Rio) para a obtenção do Título de Bacharel em Direito.

Orientador: PROF. PAULO FREITAS RIBEIRO Co-orientador: PROF. DIOGO MALAN 
À minha família, pelo carinho e apoio incondicional.

Ao William, pelo amor e preciosa companhia. 


\section{Agradecimentos}

Inicialmente, agradeço ao Professor Paulo Freitas Ribeiro, a quem tenho como um verdadeiro exemplo a ser seguido, pelo brilhantismo e entusiasmo com que conduz sua carreira.

Ao Professor Diogo Malan, pelo seu notório compromisso com a produção de conhecimento, disponibilizando seu tempo e saber ao dirimir as dúvidas que surgiram no desenvolvimento desse trabalho.

A Camila Freitas, Rodrigo Perez, Ivan Vieira, Fabrizio Feliciano, Raquel Costa Dias, Gustavo Pirá, Juliana Jaimovich e Luisa Falcão, pelo aprendizado que me proporcionam, sempre dispostos a dividir comigo suas experiências.

À Professora Regina Soares, pela imprescindível contribuição dada ao longo do meu curso e, em especial, nessa etapa da minha formação.

Ao Professor Carlos Raymundo, pela dedicação dispensada à disciplina de Direito Penal, fazendo despertar o meu interesse.

À minha querida amiga Priscila, com quem tive a maior lição de superação e amor à vida.

A todos os meus amigos da PUC, especialmente Lola, Bruno Lúcio, Pereira e Stela, por serem verdadeiros amigos meus, estando presentes nos mais importantes momentos da faculdade. 
A minhas amigas e amigos do Colégio Teresiano, meus companheiros de vida, pelo privilégio que é crescer e me desenvolver junto a vocês.

A Bianca, um anjo no meu caminho.

A Sandra, Grécia, Valéria e Jaqueline, pela constante disposição em colaborar.

A todos os professores, amigos e funcionários que de alguma forma contribuíram para a minha formação. 


\section{Resumo:}

O presente trabalho visa realizar um estudo crítico do crime de embriaguez ao volante, tipificado no artigo 306, CTB, à luz da “administrativização" do Direito Penal e da garantia contra a autoincriminação.

A abordagem é feita a partir da constatação de que o crime em questão reflete a mudança de paradigma pela qual o Direito Penal vem passando. Mudança essa que ocorre no sentido de atribuir, ao Direito Penal, contornos do Direito Administrativo sancionador, principalmente por meio da flexibilização de seus mais importantes princípios.

Observou-se, igualmente, que a estrutura normativa do delito em questão deve ser avaliada levando-se em consideração o direito constitucional dos indivíduos a não se auto-incriminar.

Embora não esgote as controvérsias doutrinárias e jurisprudenciais, o presente estudo procurou demonstrar a relevância dos debates acerca do tema, que merecem apreciação cuidadosa, no intuito de se garantir uma aplicação do tipo penal em conformidade com a Constituição Federal.

\section{Palavras-Chave:}

Crime de embriaguez ao volante, Administrativização, Garantia contra a autoincriminação, nemo tenetur se detegere, etilômetro, bafômetro, crime de perigo. 


\section{Sumário}

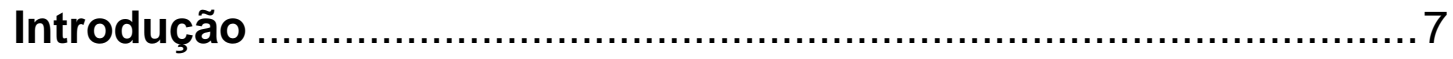

\section{A "ADMINISTRATIVIZAÇÃO” DO DIREITO PENAL .................. 9}

1.1. A "administrativização" como parte do fenômeno da expansão do direito penal. ...................................................................... 9

1.2. As diferenças entre o Direito Penal tradicional e o Direito Administrativo sancionador

1.3. As características do Direito Penal "administrativizado"

2. DO PRINCÍPIO DO NEMO TENETUR SE DETEGERE ..............28

2.1. Contextualização do princípio ..........................................28

2.2. O princípio nemo tenetur se detegere no ordenamento jurídico brasileiro e seu status constitucional ..................................33

2.3. Decorrências do princípio nemo tenetur se detegere ...........42

\section{CRÍTICA AO CRIME DE EMBRIAGUEZ AO VOLANTE .............53}

3.1. A "administrativização" do Direito Penal e o tipo objetivo do

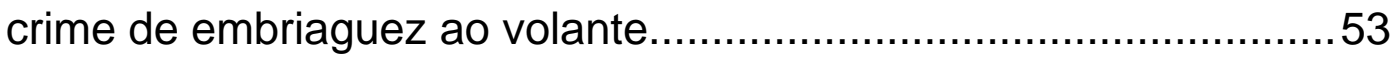

3.2. O crime da embriaguez no volante e o direito ao silêncio ....68

3.3. Interpretações que vêm sendo dadas à lei. .......................... 74

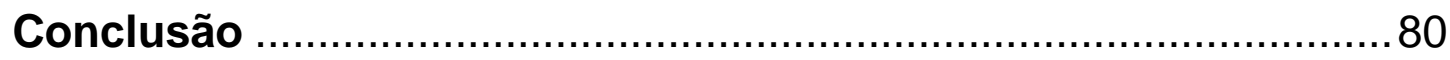

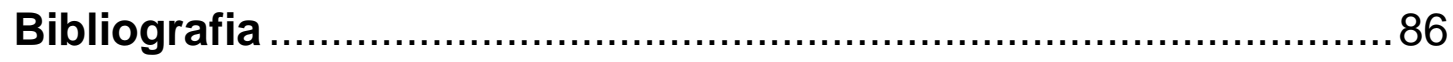




\section{Introdução}

O presente estudo, embora não tenha a pretensão de esgotar o assunto, se propõe a abordar de forma crítica a recente modificação por que passou o tipo penal do crime de embriaguez ao volante (artigo 306 do Código de Trânsito Brasileiro), promovida pela Lei 11.705/2008.

Criticar-se-á a geometria do referido tipo à luz da "administrativização" do Direito Penal e do princípio nemo tenetur se detegere.

Primeiramente, será feita uma análise do novo paradigma vivenciado pelo Direito Penal, que é a sua “administrativização”. Ver-se-á em que medida a era da globalização influencia o Direito Penal no sentido de desempenhar funções próprias do Direito Administrativo sancionador, passando o ilícito penal a ter características do ilícito administrativo.

Em seguida será abordado de que forma muitos dos mais importantes princípios penais vem sendo flexibilizados nesse processo, para que possamos entender as características desse Direito Penal “administrativizado”.

Em seguida, nos iremos nos deter no estudo do direito de não se autoincriminar, demonstrando sua importância no processo penal. Será feita uma exposição acerca de sua definitiva adoção pelo ordenamento jurídico brasileiro e seu status de norma constitucional. Por fim, estudar-se-á a sua abrangência; a quem alcança; a que tipo de provas se aplica; as obrigações geradas para as autoridades; e as decorrências de sua violação.

Após as explanações preliminares, adentraremos na análise do crime de embriaguez ao volante, a partir dos conceitos estudados. 
Veremos como era criminalizada a conduta anteriormente e de que forma a estrutura típica atual é reflexo da "administrativização” do Direito Penal.

Abordaremos a controvérsia sobre a classificação do delito, se de perigo concreto ou de perigo abstrato, e como deve ser a sua interpretação em conformidade com a Constituição Federal.

Em seguida, será exposta a relação desse tipo penal com o princípio nemo tenetur se detegere. Falaremos da controvérsia acerca da obrigatoriedade ou não da submissão ao teste do "bafômetro" e as conseqüências de uma eventual recusa por parte do condutor. Importante, também, ver como a vinculação da figura delitiva à determinada concentração de álcool no sangue pode significar a frustração da persecução penal na maioria dos casos, se devidamente respeitado esse princípio, constitucionalmente assegurado.

Em seguida, elencaremos as mais diversas interpretações que tem surgido para solucionar as controvérsias indicadas, bem como as principais críticas que podem ser feitas a elas.

Por fim, serão expostos os posicionamentos considerados mais acertados sobre o tema e o que se sugere como forma de criminalizar, em conformidade com a Constituição, a conduta de embriaguez ao volante. 


\section{A "ADMINISTRATIVIZAÇÃO" DO DIREITO PENAL}

\subsection{A "administrativização" como parte do fenômeno da expansão do direito penal.}

A “administrativização” do Direito Penal é um termo usado por JesúsMaría Silva Sánchez para denominar uma mudança de perspectiva desse ramo do Direito. Trata-se do reconhecimento de que o Direito Penal vem sofrendo um processo de banalização, sendo utilizado como instrumento de execução de políticas da Administração Pública ou de gestão de riscos sistêmicos inerentes às atividades dos diversos setores da sociedade.

Assim, pode-se dizer que o ilícito penal vem passando por uma série de modificações, não só quanto à estrutura do tipo penal e quanto à antecipação das fronteiras da proteção penal ${ }^{1}$, como também quanto às regras de imputação. Em verdade, o que se vê é que o ilícito penal ganha, progressivamente, alguns contornos do ilícito administrativo, e o Direito Penal acaba por exercer as funções do Direito Administrativo sancionador.

Quanto ao seu início, Luiz Flávio Gomes acredita que o fenômeno da “administrativização” do Direito Penal se iniciou antes da globalização, muito embora reconheça que é intensificado nesse momento ${ }^{2}$.

Para o autor, o começo se deu quando da instituição do Estado de Direito. É que, antes, os delitos bagatelares eram julgados pelas autoridades do

\footnotetext{
1 SILVA SÁNCHEZ, Jesús-María. A expansão do Direito Penal: aspectos da política criminal nas sociedades pós-industriais. $2^{\mathrm{a}}$ edição, São Paulo: Editora Revista dos Tribunais, 2002, p. 113.

2 "Particularmente agora, em que é maior a consciência de todos em relação aos riscos e ameaças decorrentes do processo de globalização da economia, das finanças e da informatização, acentuou-se o uso (indiscriminado) do Direito penal, especialmente nesse âmbito "bagatelar". O que era até pouco tempo objeto de regulação meramente acessória (Nebensstrafrecht ou Direito penal meramente sancionador) passou para o âmbito do Direito penal principal, sujeitando-se às suas clássicas sanções penais (sem se descartar obviamente a pena privativa de liberdade)". (GOMES, Luiz Flávio e BIANCHINI, Alice. O direito penal na era da gloabalização: hipertrofia irracional (caos normativo), instrumentalização distorciante... São Paulo: Editora Revista dos Tribunais, 2002, p. 48/49).
} 
Império e da Igreja, de forma arbitrária, baseando-se tão-somente em favoritismo e corrupção. Com o advento do Estado de Direito, entretanto, todos esses julgamentos passaram a centralizar-se nas mãos dos juízes, em conformidade com regras pré-estabelecidas.

Nessa transição, que o autor identifica como o nascimento do positivismo, os delitos bagatelares, ainda que representassem meras transgressões a modelos administrativos e simples contravenções, foram incorporados ao Direito Penal e, assim, se teria o início da “administrativização” do Direito Penal ${ }^{3}$.

Silva Sánchez, por sua vez, volta sua análise para a expansão do Direito Penal nas sociedades pós-industriais, relacionando a questão da “administrativização” do Direito Penal com as políticas criminais da era da globalização.

Referimo-nos à globalização planetária, que vem sendo favorecida pelos avanços da tecnologia da informação, consistindo, em verdade, em uma nova era da civilização. Nela, novos bens jurídicos surgem, principalmente os de natureza supraindividual, além de se instaurar uma sensação geral (e muitas vezes apenas criada pela mídia e alimentada por políticos) de insegurança ${ }^{4}$.

3 . "Muito sintomático do fenômeno que acaba de ser exposto, como afirma Bricola, "é o histórico processo de transformação do ilícito administrativo no ilícito penal: comportamentos que no Estado de Polícia eram considerados ilícitos administrativos, desde o momento em que se instaura o Estado de direito foram transformados em infrações penais, geralmente de natureza contravencional”. O correto teria sido a jurisdicionalização do conflito, porém sem o uso indevido do Direito Penal, que em razão do seu caráter subsidiário só deve ser chamado quando há um ataque relevante para um bem jurídico de elevada importância”. (GOMES, Luiz Flávio e BIANCHINI, Alice. O direito penal na era da gloabalização: hipertrofia irracional (caos normativo), instrumentalização distorciante... São Paulo: Editora Revista dos Tribunais, 2002, p. 44/45).

4 "O mais preocupante é que essa tendência conta com ampla possibilidade de expansão, visto que, em geral, está acobertada pela "legitimação" popular. Isso conduz os políticos e a mídia a satisfazerem (sempre) esse "anseio" coletivo (leia-se: a venderem esse novo produto de mercado que se chama Direito penal): more and more of the same!” (GOMES, Luiz Flávio e BIANCHINI, Alice. O direito penal na era da gloabalização: hipertrofia irracional (caos normativo), instrumentalização distorciante... São Paulo: Editora Revista dos Tribunais, 2002, p. 128). 
Há, com isso, uma demanda pelo reforço da ordem e uma pressão por um aumento de tutela desses novos bens jurídicos. Como esse processo coincide com o descrédito de outras instâncias de proteção, acabou-se por realizar essa tutela por meio do Direito Penal ${ }^{5}$, como se observa da lição de Jesús-Maria Silva Sánchez:

O que foi mencionado acima, contudo, ainda não explicaria de modo suficiente a demanda de punição e a conseguinte expansão precisamente do Direito Penal. Com efeito, tais dados poderiam conduzir certamente a uma expansão dos mecanismos de proteção não jurídicos, ou inclusive dos jurídicos, mas não necessariamente dos jurídico-penais. Ocorre, sem embargo, que tais opções ou são inexistentes, ou parecem insuficientes, ou se acham desprestigiadas. Referimo-nos à ética social, ao Direito Civil e ao Direito Administrativo ${ }^{6}$.

Entretanto, essas novas tutelas não são próprias do Direito Penal e sua estrutura não foi pensada para realizá-las. Para esclarecer essa inadequação Luiz Flávio Gomes utiliza-se de uma analogia. O autor compara o Direito Penal a um elefante e a criminalidade da era pós-industrial a ratos por ele perseguidos. Como o elefante era lento e pesado demais para perseguir efetivamente os ratos, que estariam se tornando cada vez mais rápidos, teve de ser ele adaptado, quase deformado. Assim se fez com o Direito Penal, conforme lição de Luiz Flávio Gomes ${ }^{7}$ :

5 GOMES, Luiz Flávio e BIANCHINI, Alice. O direito penal na era da gloabalização: hipertrofia irracional (caos normativo), instrumentalização distorciante... São Paulo: Editora Revista dos Tribunais, 2002, p. 33/34.

6 SILVA SÁNCHEZ, Jesús-María. A expansão do Direito Penal: aspectos da política criminal nas sociedades pós-industriais. $2^{\mathrm{a}}$ edição, São Paulo: Editora Revista dos Tribunais, 2002, p. 57.

7 "Valendo-nos da imagem do elefante e dos ratos, dá para dar uma idéia (bastante aproximada) do que vem ocorrendo com o tradicional Direito penal, que é, em termos de velocidade, um verdadeiro elefante (tendo em conta que se funda na pena de prisão e exige, conseqüentemente, o devido processo legal clássico: investigação burocratizada, denúncias, provas, instrução demorada, contraditório, ampla defesa, sentença, recursos, tribunais lentos e abarrotados etc.). A criminalidade da era pós-industrial e, agora, da globalização, por seu turno, é velocíssima (tanto quanto os ratos).

Ao longo do século XX, mas particularmente depois da Segunda Guerra Mundial, acreditou-se que seria possível conter ou controlar ("combater") os ratos com o elefante (com o Direito penal tradicional), desde que alguma mobilidade extra lhe fosse dada. O legislador, assim, começou a sua deformação, colocando algumas rodas mecânicas nas suas patas (leia-se: para fazer frente à criminalidade moderna, começou a transformar o Direito penal tradicional flexibilizando garantias, espiritualizando o conceito de bem jurídico, esvaziando o princípio da ofensividade - mediante a construção de tipos de perigo abstrato-, eliminando grande parcela da garantia da legalidade etc.)”. 
Logo percebeu-se que a velocidade do elefante, mesmo já deformado, ainda assim, era incompatível com a rapidez da criminalidade. O processo de motorização e, depois, de turbinação de suas patas deu-se nas três últimas décadas do século XX: amplo processo de criminalização, modificação constante do Código Penal, aprovação massiva de leis especiais, incremento dos tipos de perigo abstrato, agravamento de penas, novos tipos penais, flexibilização de praticamente todas as garantias penais e processuais, corte de direitos e garantias fundamentas, flexibilização da prisão cautelar, proibição do direito de apelar, tutela prioritária de bens jurídicos supraindividuais (saúde pública, consumidor, segurança viária etc.), antecipação da tutela penal, admissão da transação penal, prêmios para o colaborador da Justiça, plea bargaining etc. Conseqüência: o elefante (Direito penal tradicional) tornou-se irreconhecível ${ }^{8}$.

Com isso, reconhece-se que o Direito Penal passa também por uma nova fase, sofrendo deformações para que lhe seja possível exercer as funções que a sociedade vem dele exigindo. Uma delas é a função de direito voltado para a gestão de riscos gerais inerentes à sociedade atual e a manutenção da boa ordem.

Nessa medida, pode-se dizer que, das muitas transformações pelas quais esse ramo do direito vem passando (“expansão” do direito penal) ${ }^{9}$, algumas o levam a desempenhar funções como a acima referida, própria do Direito Administrativo sancionador. É essa tendência que denominamos “administrativização” do direito penal.

(GOMES, Luiz Flávio e BIANCHINI, Alice. O direito penal na era da globalização: hipertrofia irracional (caos normativo), instrumentalização distorciante... São Paulo: Editora Revista dos Tribunais, 2002, p. 34/35).

8 GOMES, Luiz Flávio e BIANCHINI, Alice. O direito penal na era da globalização: hipertrofia irracional (caos normativo), instrumentalização distorciante... São Paulo: Editora Revista dos Tribunais, 2002, p. 34/35.

9 O conjunto de fenômenos sociais jurídicos e políticos relacionados à globalização vem causando no direito penal uma série de mudanças que configuram o que a doutrina costuma chamar de “expansão”. SILVA SÁNCHEZ, Jesús-María. A expansão do Direito Penal: aspectos da política criminal nas sociedades pós-industriais. $2^{\mathrm{a}}$ edição, São Paulo: Editora Revista dos Tribunais, 2002, p. 114. 
Para a compreensão das mudanças abrangidas por essa tendência, faz-se importante conferir as principais diferenças que existiam entre o Direito Penal tradicional $^{10}$ e o Direito Administrativo sancionador.

\subsection{As diferenças entre $o$ Direito Penal tradicional e o Direito Administrativo sancionador}

Ao tratar do tema da "administrativização" do Direito Penal, Silva Sánchez apontou algumas diferenças tradicionalmente existentes entre o Direito Penal e o Direito Administrativo sancionador.

Segundo o autor, teses clássicas diferenciavam o ilícito penal do ilícito administrativo de forma que o primeiro constituiria uma lesão eticamente reprovável a um bem jurídico, enquanto o segundo seria um ato éticovalorativamente neutro. Uma doutrina posterior diferenciava os dois tipos de ilícitos por um critério meramente quantitativo, que atribuía ao ilícito administrativo um menor conteúdo de injusto.

Para ele, entretanto, não se pode limitar a diferenciação tão-somente no tocante à configuração do injusto, devendo-se levar igualmente em consideração os critérios a partir dos quais se contempla o injusto, os critérios de imputação e as garantias formais e materiais que devem estar presentes quando da imposição de sanções ${ }^{11}$.

10 “É preferível falar de um direito penal "tradicional” para descrever aqueles fundamentos e princípios que em maior ou menor medida justificaram o aparecimento e desenvolvimento do direito penal entendido como poder do Estado, como ordem normativa e como saber jurídico". (GOMES, Luiz Flavio e YACOBUCCI, Guillhermo Jorge. As grandes transformações do direito penal tradicional, São Paulo, Editora Revista dos Tribunais, 2005, p. 29)

11 SILVA SÁNCHEZ, Jesús-María. A expansão do Direito Penal: aspectos da política criminal nas sociedades pós-industriais. $2^{\mathrm{a}}$ edição, São Paulo: Editora Revista dos Tribunais, 2002, p.115/116. 
Isto é, há diferenças qualitativas, como a necessária sujeição a um juiz, no caso do Direito Penal e a impossibilidade de a Administração Pública estabelecer penas privativas de liberdade, no que se refere ao Direito Administrativo. Essa diferenciação qualitativa acaba por ter reflexo principalmente na forma de entender a lesividade de cada espécie de infração e nos critérios utilizados para sua imputação.

Analisando essas classes de infrações do ponto de vista teleológico, pode-se observar que o Direito Penal visa proteger bens jurídicos concretos, seguindo critérios de lesividade concretos e de imputação individual de um injusto. Por sua vez, o Direito Administrativo busca a ordenação de um modo geral, a organização dos setores da atividade. Sua finalidade é reforçar um modelo de gestão setorial através da imposição de sanções a eventuais desobediências.

Como seu objetivo consiste meramente em ordenar setores, a visão do Direito Administrativo se diferenciava do Direito Penal também por ter uma análise necessariamente global, de afetação geral, estatística. A avaliação de condutas não se dá de forma particularizada e o foco se volta ao conjunto, em uma perspectiva macrossocial e macroeconômica, não em comportamentos de sujeitos individualmente considerados, como ocorria no Direito Penal.

É por isso, também, que o potencial ofensivo da conduta era avaliado de forma diversa. Enquanto no Direito Penal tradicional as condutas deveriam ser lesivas per si, ou seja, o comportamento de um só indivíduo deveria ter a potencialidade de afetar um determinado bem jurídico, no Direito Administrativo sancionador, isso era diverso. Neste, o que se avalia é se aquele gênero de condutas representava um risco para o modelo de gestão de determinado setor, como bem explica o autor: 
Precisamente por ser essa sua perspectiva própria, o Direito Administrativo sancionador não precisa, para sancionar, que a conduta específica, em si mesma concebida, seja relevantemente perturbadora de um bem jurídico, e por tal razão tampouco é necessária uma análise de lesividade no caso concreto. Do mesmo modo, tampouco parece haver óbices a aceitação de que o direito administrativo sancionador se oriente por critérios de legalidade na persecução dos ilícitos, senão por puros critérios de oportunidade. O que é necessário, mais que tudo é que o gênero de condutas represente, em termos estatísticos, um perigo para o modelo setorial de gestão ou, se se prefere, em termos menos tecnocráticos, para a boa ordem do setor de atividade determinado ${ }^{12}$.

Seguindo essa mesma linha, verifica-se que, enquanto o dano, no Direito Penal tradicional, era produzido por uma única conduta, no Direito Administrativo sancionador, esse dano tende a ser cumulativo, derivado da repetição, sendo ofensiva somente na medida em que se repetisse. A sua pergunta chave, em verdade, é: “o que aconteceria se todos os intervenientes neste setor de atividade realizassem a conduta $X$ - quando existe, ademais, uma séria probabilidade de que muitos deles o façam - caso fosse considerada lícita?”13

Deste modo, chega-se a outra diferença, decorrente da anteriormente mencionada. Enquanto o Direito Penal tradicional só punia uma conduta que oferecesse perigo concreto para um bem jurídico penalmente tutelado, no Direito administrativo sancionador, ao contrário, não é necessário que uma dada conduta isoladamente considerada ofereça perigo ao bem jurídico. A lição é posta por Silva Sánchez nos seguintes termos:

Essa diferença é substancial, e explica, em primeiro lugar que a tipificação de infrações administrativas, ainda que pretenda certamente cumprir funções de proteção social - e de fato as cumpram desde essa perspectiva global, macroeconômica ou macrossocial -, muitas vezes somente adquire referido tom material se as infrações se contemplam em conjunto. Em contrapartida, contempladas

12 SILVA SÁNCHEZ, Jesús-María. A expansão do Direito Penal: aspectos da política criminal nas sociedades pós-industriais. $2^{\mathrm{a}}$ edição, São Paulo: Editora Revista dos Tribunais, 2002, p.117.

13 SILVA SÁNCHEZ, Jesús-María. A expansão do Direito Penal: aspectos da política criminal nas sociedades pós-industriais. $2^{\mathrm{a}}$ edição, São Paulo: Editora Revista dos Tribunais, 2002, p.117. 
uma a uma revelam-se, certamente, formais, isto é, muitas vezes nem sequer de perigo abstrato, senão de mero perigo global, estastístico, presumido etc ${ }^{14}$.

As diferenças entre o Direito Administrativo sancionador e o Direito Penal tradicional foram ilustradas com diversos exemplos, mais especificamente no tocante ao tráfego de veículos, no âmbito tributário, na proteção do meio ambiente, em matéria de entorpecentes e um no tocante à ordem econômica.

Para esse trabalho, o exemplo mais relevante, que será mais bem desenvolvido posteriormente, é o primeiro, como veremos abaixo:

O limite da infração administrativa em matéria de tráfego de veículos é de 0,5 mg de álcool por litro de sangue, segundo a normativa espanhola. Obviamente, tal limite, ou inclusive um inferior, pode estar plenamente justificado sob perspectivas globais de ordenação do setor, inclusive com base em dados estatísticos. Desde logo, a maioria das pessoas representa um perigo para a circulação se seu sangue apresenta esta concentração de álcool, mais ainda, em termos de gestão administrativa do risco de circulação - redução das enormes cifras anuais de mortes nas estradas - pode ter inclusive sentido o limite absoluto de $0 \mathrm{mg}$ de álcool por litro de sangue, cuja superação conduziria a infração administrativa, mas vejamos, tal critério por si só não é operativo no âmbito jurídico-penal. Pois aí não interessa o aspecto estatístico, senão se a pessoa cuja conduta está sob exame judicial, pôs realmente em perigo bens jurídicos ou não. E aqui a apreciação estatística pode somente constituir uma presunção contra reo, a qual, em princípio, não constitui base suficiente para imputação ${ }^{15}$.

Uma vez entendidas as peculiaridades tradicionalmente existentes em cada um desses dois ramos do Direito, estudaremos as características do Direito Penal tradicional que, entre suas mudanças, vem dando lugar a um Direito Penal “administrativizado”.

14 SILVA SÁNCHEZ, Jesús-María. A expansão do Direito Penal: aspectos da política criminal nas sociedades pós-industriais. $2^{\mathrm{a}}$ edição, São Paulo: Editora Revista dos Tribunais, 2002, p.118.

15 SILVA SÁNCHEZ, Jesús-María. A expansão do Direito Penal: aspectos da política criminal nas sociedades pós-industriais. $2^{\mathrm{a}}$ edição, São Paulo: Editora Revista dos Tribunais, 2002, p.118. 


\subsection{As características do Direito Penal "administrativizado"}

Como vimos anteriormente, havia uma série de características e finalidades que diferenciavam o Direito Penal tradicional do Direito Administrativo sancionador.

Ocorre que o Direito Penal tradicional vem passando pelas mais diversas transformações, estando em uma transição do modelo "delito de lesão de bens individuais" para o modelo "delito de perigo presumido para bens supraindividuais”.

Essa transição representa uma diminuição nas mencionadas diferenças, e o Direito Penal passa a ter atributos desse outro ramo do direito. Nessa medida, podemos dizer que o Direito Penal está "administrativizado”.

Esse processo de transformação se caracteriza por mudança na formação de novos tipos penais, em sua estrutura, em suas regras de imputação, sendo necessário estudar, afinal, como é o Direito Penal “administrativizado", principalmente por meio de uma comparação com as características marcantes de um direito Direito Penal efetivamente adequado ao Estado democrático de Direito.

Tanto Silva Sánchez como Luiz Flávio Gomes, em sua abordagem do tema, nos ensina que essa mudança de perspectiva acaba por violar uma série de princípios penais tradicionais, como os princípios da exclusiva proteção de bens jurídicos, da ofensividade, da culpabilidade, da proporcionalidade, da subsidiariedade, etc. Faz-se necessário analisar mais atentamente em que medida a violação a alguns deles “administrativiza” o Direito Penal. 
Inicialmente, cabe relembrar que o Direito Penal foi pensado para ser regido pelo princípio da exclusiva proteção de bens jurídicos, cujo significado pode-se extrair da lição de Luiz Flávio Gomes:

A função principal do princípio da exclusiva proteção de bens jurídicos é a de delimitar uma forma de Direito penal, o Direito penal do bem jurídico, daí que não seja tarefa sua proteger a ética, a moral, os costumes, uma ideologia, uma determinada religião, estratégias sociais, valores culturais como tais, programas de governo, a norma penal em si etc. O Direito penal, em outras palavras, pode e deve ser conceituado como um conjunto normativo destinado à tutela de bens jurídicos, isto é, de relações sociais conflitivas valoradas positivamente na sociedade democrática ${ }^{16}$.

A tentativa de formular uma definição precisa de bem jurídico sempre foi um problemática do Direito Penal. A ausência dessa definição consiste em um dos fatores que deu margem para que ocorresse a "administrativização" do Direito Penal. Nesse sentido, outro esclarecedor ensinamento de Luiz Flávio Gomes, ao tratar especificamente desse tema:

Para esse anômalo e preocupante quadro de indescritível hipertrofia, ou seja, de aumento gradual e constante do número de ilícitos penais, não há dúvida de que também muito contribuiu a ausência de individualização de um substrato material do conceito de bem jurídico com capacidade não somente para distinguir com segurança o ilícito penal do administrativo, senão sobretudo para limitar as decisões (seletivas) do legislador no momento da criminalização primária (leia-se: no momento da tipificação formal da conduta) ${ }^{17}$.

Com o advento da globalização, que se caracteriza pela presença de numerosos novos riscos e pelo surgimento de novos bens jurídicos, esse conceito ficou ainda menos delineado. Sem um conteúdo delimitado do conceito de bem jurídico, acabou-se agravando o processo de

16 GOMES, Luiz Flavio. Princípio da ofensividade no direito penal: não há crime sem lesão ou perigo concreto de lesão ao bem jurídico (nullum crimen sine iniuria), funções político-criminal $e$ dogmático-interpretativa, o princípio da ofensividade como limite do ius puniendi, o princípio da ofensividade como limite do ius poenale, São paulo: editora revista dos tribunais, 2002, p. 43.

17 GOMES, Luiz Flávio e BIANCHINI, Alice. O direito penal na era da globalização: hipertrofia irracional (caos normativo), instrumentalização distorciante... São Paulo: Editora Revista dos Tribunais, 2002, p. 43. 
“administrativização” do Direito Penal ${ }^{18}$, de forma que não tem sido possível evitar que ocorra uma proliferação indiscriminada dos "ilícitos administrativos com a etiqueta de ilícitos penais”. ${ }^{19}$

Assim, pode-se concluir que, como uma primeira característica do Direito Penal "administrativizado", tem-se que não vem ele tutelando tãosomente bens jurídicos substanciais da pessoa humana, os autênticos bens jurídicos que merecem a proteção por meio de sanção assentada na pena privativa de liberdade.

Passou, em verdade, a tutelar, igualmente, políticas da administração pública, a atividade administrativa em si mesma considerada, a atuação do Estado como agente fiscalizador, os modelos de gestão setoriais e os bens jurídicos supraindividuais, ou seja, contextos mais genéricos e abrangentes (como o meio ambiente, a ordem econômica, o sistema financeiro, o trânsito de veículos, etc $)^{20}$.

18 "Um outro momento crítico dessa instrumentalização estamos vivendo agora, neste princípio de novo milênio, isto é, na era da globalização, que se caracteriza pela presença de riscos (alguns reais, outros fantasiosos) inerentes à sociedade tecnologicamente avançada. A grande ameaça, agora, depois da queda do muro de Berlim (1989), já não vem representada pelo comunismo, senão pelos riscos que permeiam nossa sociedade difusa e complexa, que enfrenta enfermidades incuráveis (AIDS) ou epidêmicas (dengue, por exemplo), conseqüências nefastas de difícil controle (vacas loucas), grandes catástrofes ecológicas (Chernobil), máfias, corrupção generalizada, crime organizado (inclusive dentro dos presídios - PCC, megarrebeliões), terrorismo etc”. (GOMES, Luiz Flávio e BIANCHINI, Alice. O direito penal na era da globalização: hipertrofia irracional (caos normativo), instrumentalização distorciante... São Paulo: Editora Revista dos Tribunais, 2002, p. 76/77)

19 "Particularmente agora, em que é maior a consciência de todos em relação aos riscos e ameaças decorrentes do processo de globalização da economia, das finanças e da informatização, acentuou-se o uso (indiscriminado) do Direito penal, especialmente nesse âmbito "bagatelar". O que era até pouco tempo objeto de regulação meramente acessória (Nebensstrafrecht ou Direito penal meramente sancionador) passou para o âmbito do Direito penal principal, sujeitando-se às suas clássicas sanções penais ( sem se descartar obviamente a pena privativa de liberdade)". (GOMES, Luiz Flávio e BIANCHINI, Alice. O direito penal na era da globalização: hipertrofia irracional (caos normativo), instrumentalização distorciante... São Paulo: Editora Revista dos Tribunais, 2002, p. 48/49).

20 "O risco mais concreto decorrente dessa universalização dos bens jurídicos consiste na utilização ("perversão") do Direito penal para a tutela de "funções" ou "instituições", que não representam "autênticos" bens jurídicos (ou bens "substanciais" da pessoa humana). Em nome ou "por causa" dos riscos permanentes que a globalização vem criando ou forjando (riscos reais, riscos imaginários), o Direito penal vai avançando velozmente a cada dia (ora para a tutela dos bens jurídicos vagos - ordem financeira, ordem econômica, relações de consumo etc. -, ora para a proteção de funções ou 


\section{Nesse sentido, o entendimento de Alessandro Baratta:}

Tal termo [a "administrativização] nos indica dois fatos que, apesar de complementares, são distintos: em primeiro lugar está o fato de que a maior parte das normas penais - produzidas pelos legisladores em número cada vez maior, juntamente com os códigos e também algumas leis de reformas destes mesmos códigos [...], sejam normas penais acessórias às normas e à atividade administrativa do Estado e das instituições públicas”²1.

Quanto a esse ponto, vale conferir a observação de Luiz Flávio Gomes, no sentido de haver uma distorção entre o tipo de pena imposta pelo Direito Penal e esses novos objetos de proteção:

Nenhuma afetação de um bem jurídico supraindividual, por si só, pode ter validade no Direito penal que envolve o ius libertati. Os bens supraindividuais foram imaginados para a tutela de bens pessoais. É essa a perspectiva correta que deve guiar a interpretação de todos os tipos penais ${ }^{22}$.

Um segundo aspecto do Direito Penal “administrativizado” tem relação estreita com o princípio visto e se dá no tocante ao princípio da ofensividade.

É que esses novos objetos de proteção carecem de uma técnica de tutela que se caracteriza por ser excessivamente adiantada (de perigo abstrato,

instituições etc.)". (GOMES, Luiz Flávio e BIANCHINI, Alice. O direito penal na era da globalização: hipertrofia irracional (caos normativo), instrumentalização distorciante... São Paulo: Editora Revista dos Tribunais, 2002, p. 81/82). Essa tendência fica também em evidência no seguinte trecho: "Inclusive no nosso tempo há um forte interesse em obter por meio das leis penais a mera obediência a deveres de ordem administrativa, econômica e financeira, que estão muito distantes da configuração de um bem jurídico com conteúdo determinado. Nesses casos, certamente, o legislador quer lograr obter o cumprimento de certas obrigações, algumas delas meramente formais". (GOMES, Luiz Flavio e YACOBUCCI, Guillhermo Jorge. As grandes transformações do direito penal tradicional, São Paulo, Editora Revista dos Tribunais, 2005, p. 75/76)

21 BARATTA, Alessandro. Funções instrumentais e simbólicas do direito penal: lineamentos de uma teoria do bem jurídico. Revista Brasileira de Ciências Criminais. São Paulo, v. 2, n. 5, jan./mar. 1994, p. 12.

22 GOMES, Luiz Flávio e BIANCHINI, Alice. O direito penal na era da globalização: hipertrofia irracional (caos normativo), instrumentalização distorciante... São Paulo: Editora Revista dos Tribunais, 2002, p. 81. Silva Sánchez, porém, alerta que "No caso de proteção dos bens supraindividuais como o meio ambiente e o âmbito socioeconômico, se tornou majoritária a tese de que a referência aos interesses individuais que se vem contextualizados por aqueles é mera ratiolegis, não sujeito à comprovação quando aplicado o tipo ao caso concreto, ou seja, o protegido é simplesmente o contexto com o que se assenta progressivamente a tendência de provocar a intervenção do direito penal, tão logo seja afetado um certo ecossistema em termos que superam os padrões administrativos estabelecidos”. (SILVA SÁNCHEZ, Jesús-María. A expansão do Direito Penal: aspectos da política criminal nas sociedades pós-industriais. $2^{\mathrm{a}}$ edição, São Paulo: Editora Revista dos Tribunais, 2002, p. _) 
infração de mera desobediência etc. $)^{23}$, conforme explica o mencionado Professor:

As razões para esse adiantamento da tutela penal residiram em que uma lesão desses bens macrossociais seria de tamanha importância que a função do direito penal resultaria inútil (não se pode esperar a lesão deve-se punir desde logo o perigo). Os tipos penais de perigo abstrato admitem um "adiantamento" e a aplicação da sanção só com o comprovar-se que se superou o padrão de risco socialmente permitido ${ }^{24}$.

Enfraquece-se, assim, o princípio da ofensividade que

nada diz diretamente sobre a missão do Direito penal, senão que expressa uma forma de compreender ou de conceber o delito: o delito como ofensa a um bem jurídico. E disso deriva, como já afirmamos tantas vezes, a inadmissibilidade de outra forma de delito: mera desobediência, simples violação da norma imperativa etc.) ${ }^{25}$.

\section{O Direito Penal vem adotando essa forma própria de tutela desses}

novos objetos de proteção, de contextos cada vez mais abrangentes e de dimensões tais, que as condutas, individualmente consideradas, não os atingem de forma expressiva. Acaba, assim, punindo condutas que não são lesivas em si mesmas, conforme lição de Silva Sánchez:

Essa orientação à proteção de contextos cada vez mais genéricos (no espaço e no tempo), na fruição dos bens jurídicos clássicos leva o direito penal a relacionar-se com fenômenos de dimensões estruturais globais ou sistêmicas no que as aportações individuais autonomamente contempladas são, ao contrário, de “intensidade baixa”" 26 .

23 "Impõe-se sublinhar, destarte, que o problema da tutela preferencial dos bens supraindividuais não reside tanto na eleição desses bens para a atual configuração do (hipertrofiado) Direito penal, senão sobretudo na forma (a técnica) de tutela, excessivamente adiantada (v.g.: perigo abstrato, infração de mera desobediência etc.). Depois, na forma de interpretação desses tipos penais”. (GOMES, Luiz Flávio e BIANCHINI, Alice. O direito penal na era da globalização: hipertrofia irracional (caos normativo), instrumentalização distorciante... São Paulo: Editora Revista dos Tribunais, 2002, p. 82/83)

24 GOMES, Luiz Flavio e YACOBUCCI, Guillhermo Jorge. As grandes transformações do direito penal tradicional, São Paulo, Editora Revista dos Tribunais, 2005, p. 45.

25 GOMES, Luiz Flavio. Princípio da ofensividade no direito penal: não há crime sem lesão ou perigo concreto de lesão ao bem jurídico (nullum crimen sine iniuria), funções político-criminal $e$ dogmático-interpretativa, o princípio da ofensividade como limite do ius puniendi, o princípio da ofensividade como limite do ius poenale, São paulo: editora revista dos tribunais, 2002, p. 43.

26 SILVA SÁNCHEZ, Jesús-María. A expansão do Direito Penal: aspectos da política criminal nas sociedades pós-industriais. 2a edição, São Paulo: Editora Revista dos Tribunais, 2002, p. 114. 
Em razão disso, o Direito Penal, que era voltado para a punição de condutas individuais, contra um fato lesivo delimitado, com um sujeito ativo e passivo identificáveis, passa a ser um direito voltado à gestão de riscos gerais, inerentes às diversas atividades e contextos da sociedade.

Torna-se, deste modo, um direito que se preocupa com as grandes cifras e não com fatos isolados. Tanto isso é verdade que o Direito Penal moderno tem tipos penais que descrevem condutas que só são capazes de atingir ou colocar em perigo efetivo o bem jurídico tutelado se repetidas diversas vezes. Seria esse o chamado paradigma dos delitos de acumulação, segundo o qual

é possível sancionar penalmente uma conduta individual ainda quando esta não seja em si mesma lesiva do bem jurídico (nem o ponha por si só em perigo relevante), se se conta com a possibilidade certa de que dita conduta - não lesiva de per se - se realize também por outros sujeitos, de modo que o conjunto de comportamentos culminará certamente lesionando o correspondente bem jurídico ${ }^{27}$.

De acordo com essa teoria, devem-se considerar típicas determinadas condutas que, consideradas em si mesmas, sequer ponham em perigo abstrato o bem jurídico tutelado. Os defensores desse paradigma acreditam que tais condutas devam ser tidas como formal e materialmente típicas, pois sua repetição ou acumulação pode produzir conseqüências lesivas.

Trata-se de um modo de pensar novo para o penalista, que não precisava - sequer deveria - se perguntar sobre o que ocorreria se todas as pessoas fizessem o mesmo. É de se ressaltar, aliás, que a acumulação não seria, nesses casos, um mero elemento acidental, mas assume-se de antemão que o mesmo ato concreto será praticado por múltiplos sujeitos ${ }^{28}$.

27 SILVA SÁNCHEZ, Jesús-María. A expansão do Direito Penal: aspectos da política criminal nas sociedades pós-industriais. 2a edição, São Paulo: Editora Revista dos Tribunais, 2002, p. 121.

28 "São estes os chamados "delitos cumulativos (ou acumulativos)" [...], cuja relevância penal se pretende assentar na adoção de uma perspectiva aparentemente alheia ao modo de pensar do penalista: what if everybody did it? O que ocorreria se todos fizessem o mesmo? Pois se trata de casos em que a conduta individualmente considerada não provoca um risco relevante (ou seja, harmless), enquanto, 
Tratando do tema, Ana Elisa Bechara traz um relevante argumento no sentido de que tal forma de avaliar condutas pode representar um retrocesso no Direito Penal:

De outro lado, a adoção de um Direito Penal do comportamento, baseado nos medos sociais e no princípio da precaução, ainda que se advogue a tutela indireta de bens jurídicos supraindividuais, leva ao retrocesso da intervenção penal ao período préiluminista, não sendo difícil também a aproximação desse modelo ao relativismo axiológico que deu margem à adoção de sistemas autoritários a exemplo da escola de Kiel. O delito deve ser um comportamento socialmente danoso. A exigência do requisito básico da ofensividade, alcançado na época da Ilustração, tem raízes históricas mais profundas do que a própria Constituição atual e é imprescindível para a argumentação teleológica no campo do ilícito penal, de forma que renunciar a esse princípio significaria renunciar ao próprio Estado Democrático de Direito e permitir, já num âmbito autoritário, a punição da mera vontade ou da periculosidade. E de nada adianta pretender buscar a ofensividade fora da esfera de comportamento do agente, relacionando-a com situações concretas onde já há exposição do bem jurídico a dano. Nesses casos, parece que o efeito do entorno sobre a significação penal da conduta do agente é justamente o contrário (imagine-se a conduta de descartar ínfima quantidade de substância poluente em rio já poluído), vale dizer, o comportamento do agente terá logicamente menos relevância jurídico-penal - nos âmbitos objetivo e subjetivo - em relação ao resultado ${ }^{29}$.

Augusto Silva Dias, por sua vez, afirma que há relevantes motivos para considerar inválida e, até mesmo, inconstitucional a punição de crimes cumulativos:

Devo concluir da argumentação expendida que a capacidade de ressonância do discurso jurídico-penal aos delitos cumulativos é nula. [...] Defendo, no entanto, que tais figuras constituem exemplo paradigmático da administrativização do Direito Penal e de flexibilização das categorias centrais da imputação jurídico penal. [...] considero haver fundamento para impugnar a validade e a constitucionalidade da incriminação e punição dos contributos cumulativos ${ }^{30}$.

por outro lado, se admite que "general performance would be harmful" e que sua prática por uma pluralidade de pessoas não constitui simplesmente uma hipótese, senão uma realidade atual ou iminente”. (SILVA SÁNCHEZ, Jesús-María. A expansão do Direito Penal: aspectos da política criminal nas sociedades pós-industriais. $2^{\mathrm{a}}$ edição, São Paulo: Editora Revista dos Tribunais, 2002, p. 121).

29 BECHARA, Ana Elisa Liberatore S. Delitos de acumulação e racionalidade da intervenção penal. In Boletim IBCCRIM. São Paulo : IBCCRIM, ano 17, n. 208, , mar., 2010, p. 4.

30 DIAS, Augusto Silva. What if everybody did it? Sobre a (in)capacidade de ressonância do direito penal à figura da acumulação. Revista Portuguesa de Ciência Criminal. Coimbra, ano 13, p. 303-345, jul./set. 2003, p. 345. 
Silva Sánchez, não ignorando que condutas não ofensivas quando isoladamente consideradas podem ser extremamente lesivas quando contempladas em conjunto, faz uma importante ressalva:

O que referido anteriormente não pretende afirmar que acumulação careça de qualquer sentido para o Direito Penal. É certo que em tais casos cabe sopesar o fato de que as aportações, irrelevantes por separado, podem em seu conjunto ser relevantemente lesivas. Mas em nenhum caso pode desconsiderar-se aqui a confrontação com o princípio de proporcionalidade. Assim, a magnitude do problema global não pode nunca justificar a imposição de uma pena grave a sujeitos individuais, quando as contribuições de cada um são, isoladamente, insignificantes. O setor de ordenamento que, por suas características, melhor se adapta a casos dessa configuração é o Direito Administrativo. Se se pretende que o Direito Penal mantenha, por razões comunicativas, essa função que já assumiu e que em termos puros não lhe corresponde, deve se deixar claro que não cabe integrá-la no Direito Penal nuclear da pena privativa de liberdade, senão, em todo caso, em Direito Penal fronteiriço, que ao admitir fatos dessas características se mostraria como amplamente flexibilizado e que não poderia impor penas de prisão ${ }^{31}$.

Desse modo, podemos identificar como uma segunda característica do Direito Penal "administrativizado" a punição de condutas com baixo (ou nenhum) potencial de lesar qualquer bem jurídico relevante, pelo menos não quando isoladamente contempladas, mas somente quando analisadas em termos estatísticos, macrossociais. Não há, assim, um respeito pleno ao princípio da ofensividade, seja na formação de tipos penais, seja no momento da subsunção do fato à norma.

Nessa linha, podemos constatar que esse novo paradigma do Direito Penal se manifesta também pela violação a outro princípio basilar do Direito Penal tradicional: o princípio da culpabilidade.

É que, na contramão do que orienta esse princípio, no sentido de que não pode ser castigado aquele que atua sem culpabilidade e que a pena não pode superar a medida da culpabilidade ${ }^{32}$, esse novo modo de racionalizar

31 SILVA SÁNCHEZ, Jesús-María. A expansão do Direito Penal: aspectos da política criminal nas sociedades pós-industriais. $2^{\mathrm{a}}$ edição, São Paulo: Editora Revista dos Tribunais, 2002, p. 123/124. 32 MIRABETE, Julio Fabbrini. Manual de direito penal, 22 ed., São Paulo: Atlas, 2005, p. 196. 
acaba por fundamentar a sanção em algo alheio à conduta, já que esses riscos não são gerados por uma atuação individual, mas por problemas sistêmicos.

Além disso, esse Direito Penal preocupado com as grandes cifras vai de encontro também ao princípio da proporcionalidade. Isso porque não há uma lesão ou grave perigo para um bem jurídico correspondente a conduta de determinado indivíduo, sendo, assim, a sanção penal desproporcional ao atuar individual. Afinal, embora a lesão ou perigo seja causado por múltiplos sujeitos, a pena não é distribuída proporcionalmente às aportações individuais.

Por fim, deve-se reconhecer que o Direito Penal "administrativizado" também não se rege pelo princípio da subsidiariedade ou da última ratio. Segundo Luiz Flávio Gomes, esse princípio significa que não basta que haja um fato lesivo intolerável a um bem jurídico relevante descrito em lei. É preciso, também, que não haja outros meios mais adequados para castigá-lo ${ }^{33}$.

Na verdade, essa é uma característica inerente a esse novo paradigma, visto que o que se quer dizer é justamente que o Direito Penal está desempenhando funções que poderiam ser mais bem desempenhadas pelo Direito Administrativo sancionador, por lhe serem próprias. Então, em todos esses casos que estão sendo abarcados pelo Direito Penal, acredita-se que ele não deveria estar sendo o meio utilizado, não sendo a ultima ratio, como deveria ser.

Em suma, constata-se que o Direito Penal vem se transformando para se adequar às demandas que dele se faz na sociedade da era da globalização. Ocorre que a conseqüência disso tem sido a sua desfiguração, com

33 GOMES, Luiz Flavio. Princípio da ofensividade no direito penal: não há crime sem lesão ou perigo concreto de lesão ao bem jurídico (nullum crimen sine iniuria), funções político-criminal $e$ dogmático-interpretativa, o princípio da ofensividade como limite do ius puniendi, o princípio da ofensividade como limite do ius poenale, São paulo: editora revista dos tribunais, 2002, p.44/45. 
considerável flexibilização de seus princípios garantidos pelo Estado democrático de direito.

O Direito Penal encontra-se, assim, expandido e, em certa medida, sofre um processo de vulgarização, banalização, que vem sendo usado como instrumento de execução de políticas da Administração Pública ou de gestão dos riscos sistêmicos inerentes às funções da Administração Pública. Assim, o ilícito penal confunde-se cada vez mais com ilícito administrativo. É nessa medida que se diz que há uma mudança de paradigma, ocorrendo a “administrativização” do Direito Penal, conforme conclusão irretocável de Silva Sánchez:

Pois bem, é possível afirmar que é uma característica do Direito Penal, das sociedades pós-industriais a assunção, em ampla medida, de tal forma a racionalizar, a da lesividade global derivada de acumulações ou repetições, tradicionalmente própria do Administrativo. É isso que se quer indicar quando se alude ao processo de "administrativização", em que, a nosso juízo, se acha imerso o direito penal. E tal poderia nos levar ainda mais longe: assim, não somente afirmar que o Direito Penal assume o modo de racionalizar próprio do Direito Administrativo sancionador, senão que inclusive, a partir daí, se converte em Direito de gestão ordinária de grandes problemas sociais $^{34}$.

E, ao que parece, é essa a tendência do Direito Penal do futuro, de acordo com esclarecedora lição de Feijóo Sanchez: (tradução livre)

Em grande medida, o Direito penal do futuro está condicionado pela dogmática dos denominados delitos de perigo. Com referência a esses delitos, se delineiam questões básicas do Direito penal moderno: a renúncia à causalidade como elemento do tipo, o papel político-criminal e dogmático da teoria do bem jurídico, o princípio da intervenção mínima, a distinção material entre injusto penal e injusto administrativo, etc. A discussão sobre o Direito penal na atual sociedade de risco, o denominado Direito Penal do risco, determinará, em grande medida, o Direito penal do futuro e as políticas legislativas que tentam resolver os principais conflitos sociais ${ }^{35}$.

34 SILVA SÁNCHEZ, Jesús-María. A expansão do Direito Penal: aspectos da política criminal nas sociedades pós-industriais. 2a edição, São Paulo: Editora Revista dos Tribunais, 2002, p. 120.

35 FEIJÓO SÁNCHEZ, Bernardo J. Cuestiones básicas de los delitos de peligro abstracto y concreto em relacion com el transito. Revista da Ajuris. Porto Alegre. v.26. n.78., 4. jun. 2000, p. 290/291. No original: "En gran medida El Derecho penal Del futuro está condicionado por la dogmática de los denominados delitos de peligro. Con referencia a estos delitos se plantean cuestinones básicas Del Derecho penal moderno: la renuncia a la causalidad como elemento del tipo, el papel político-criminal 
y dogmático de la teoria del bien jurídico, el principio de intervención mínima, la distinción material entre injusto penal y injusto administrativo, etc. La discusión sobre el Derecho penal en la actual sociedade del riesgo o el denominado Derecho penal del riesgo determinará en gran medida el Derecho penal del futuro y las políticas legislativas que intenten resolver los principales conflitos sociales”. 


\section{DO PRINCÍPIO DO NEMO TENETUR SE DETEGERE}

\subsection{Contextualização do princípio}

O privilégio contra a auto-incriminação se insere na problemática vivenciada pelos Estados democráticos de direito, que é a constante busca do equilíbrio entre direitos individuais e interesse social.

Isso porque o Estado democrático de direito tem o dever de proporcionar igualdade de oportunidade para os cidadãos e dar a assistência que for necessária, de forma a corrigir injustiças e desníveis sociais. Tal tarefa é essencialmente interventiva e pode conflitar, em certos momentos, com a sua característica de estado liberal, que respeita os absolutos valores da personalidade humana.

Essa tensão entre os direitos individuais e os interesses da coletividade se expressa de forma evidente no direito processual penal. É que esse ramo do direito, por um lado, fornece ao Estado os procedimentos a serem observados por ele para exercer seu poder punitivo, no intuito de realizar a defesa social e restaurar a paz rompida com a violação ao direito. É o processo penal que define como o Estado deve identificar, deter, condenar e aplicar a pena àqueles que praticaram crimes ${ }^{36}$.

Nesse sentido, a apuração da verdade é essencial ao direito processual penal, para que se chegue a uma sentença justa, havendo a correta aplicação do direito material ao caso concreto. É a busca da verdade que dá legitimidade aos amplos poderes investigatórios do Estado, necessariamente invasivos dos direitos fundamentais dos indivíduos.

36 DIAS NETO, Theodomiro. O Direito ao silêncio: tratamento nos direitos alemão e norteamericano. Revista brasileira de ciências criminais. São Paulo, ano 5, n.19, p. 180. 
Por outro lado, a experiência jurídica mostra que se está constantemente sujeito ao erro e, para o estado liberal, é mais repudiável a acusação e a condenação injusta do inocente do que a absolvição do culpado. Em virtude disso, há a tomada de certas precauções e a adoção de princípios humanistas como da presunção de inocência e do in dubio pro reo. Dessa forma, vê-se que a prevenção e o controle da criminalidade não são valores absolutos, devendo ser limitados.

Theodomiro Dias Neto fornece preciosa lição nesse sentido:

A eficiência na prestação da justiça penal não é, pois, um valor absoluto. Em um Estado de Direito, a persecução penal deve estar submetida ao controle do Direito. É função do direito processual penal assegurar que os métodos estatais de prevenção e controle do crime sejam compatíveis com a proteção dos direitos de personalidade do acusado, a sua privacidade, integridade moral e física, identidade pessoal. Visto desta forma, o direito processual penal não é somente veículo de realização do direito penal material, mas também direito constitucional aplicado, sendo indicador da cultura política e jurídica de uma sociedade ${ }^{37}$.

Não sendo a eficiência na prestação da justiça um valor absoluto, reconheceu-se que a busca pela verdade, se desmedida e descontrolada, pode entrar em conflito direto com os interesses fundamentais do acusado e da própria sociedade.

Por isso, em um Estado democrático de direito, a busca pela verdade, e os poderes investigatórios por ela legitimados, devem ser ponderados com o interesse de proteção dos direitos fundamentais do imputado, devendo o direito processual penal fornecer limites que atenuem os riscos inerentes ao desequilíbrio entre o Estado e o cidadão. É nesse ponto que se insere o privilégio contra a auto-incriminação, ou o princípio do nemo tenetur se detegere, que constitui um obstáculo à busca pela verdade a qualquer preço.

37 DIAS NETO, Theodomiro. O Direito ao silêncio: tratamento nos direitos alemão e norteamericano. Revista brasileira de ciências criminais. São Paulo, ano 5, n.19, p. 180. 
Nesse sentido conclui o advogado e professor David Teixeira de Azevedo:

O direito ao silêncio é um direito público subjetivo, exercido em face do Estado dentro do processo. Constitucionalmente assegurado, pode, eventualmente, colidir com valores de interesse social e público, como, p. ex., o da verdade real; todavia sempre coincidirá com o caráter ético-político do processo, que visa a um correto exercício da função jurisdicional, de modo a pacificar com justiça ${ }^{38}$.

As posições adotadas nesse exercício de ponderação revelam, no decorrer do tempo, as posturas ideológicas que prevaleciam em determinada época, ora priorizando o interesse social, e restringindo a aplicação desse princípio, ora dando maior ênfase ao interesse individual, aplicando-o de forma mais ampla ${ }^{39}$.

O autor Theodomiro Dias Neto, uma vez mais, nos fornece uma esclarecedora analogia, ao comparar essa variação de tendência de ideologia a um pêndulo:

Este imanente esforço de compatibilização dos fins do direito processual penal poderia ser simbolizado como um pêndulo que se move entre duas posições fundamentais: o interesse de investigação (eficientismo) e o de proteção da personalidade do acusado (garantismo ${ }^{40}$.

Thiago Bottino, ao justificar a escolha do seu tema de estudo, ponderou a importância desse direito para a construção de um sistema punitivo democrático:

38 AZEVEDO, David Teixeira de. O interrogatório do réu e o direito ao silêncio. Revista dos Tribunais, ano 81, agosto de 1992, vol. 682, p. 292.

39 Maria Elizabeth Queijo define a tendência atual da seguinte maneira: "Em que pese a condição de direito fundamental do Nemo tenetur se detegere e de seu reconhecimento em diplomas internacionais de direitos humanos, registra-se forte tendência nos ordenamentos jurídicos a mitigar as garantias advindas do referido princípio, especialmente em razão do aumento crescente da criminalidade organizada e violenta, dando-se prevalência ao interesse do Estado e da sociedade na persecução penal, tanto no âmbito do interrogatório quanto nas provas que dependem da colaboração do acusado para sua proteção”. (QUEIJO, Maria Elizabeth. O Direito de não produzir prova contra si mesmo (o princípio nemo tenetur se detegere e suas decorrências no processo penal. São Paulo, Editora Saraiva, 2009, p. 423)

40 DIAS NETO, Theodomiro. O Direito ao silêncio: tratamento nos direitos alemão e norteamericano. Revista brasileira de ciências criminais. São Paulo, ano 5, n.19, p. 182. 
Em segundo lugar, a escolha é resultado do reconhecimento de que tal garantia desempenha um papel estruturante na construção de um sistema punitivo compatível com um Estado Democrático de Direito. Embora haja outras garantias igualmente fundamentais - tais como o juiz natural, o devido processo legal, o contraditório e a ampla defesa, a vedação de provas ilícitas, a presunção de inocência, etc. -, o regime jurídico da auto-incriminação é crucial para a diferenciação entre dois modelos opostos de sistema punitivo: o modelo democrático e o modelo autoritário ${ }^{41}$.

Essa importância se dá devido ao fato de esse princípio assegurar ao acusado o direito de não se auto-incriminar, daí se extraindo que deve o acusado ter sua dignidade respeitada no interrogatório e que as provas contra si devem ser colhidas sem sua cooperação. Esse entendimento só foi possível a partir da concepção de que o acusado não pode mais ser tratado como objeto do processo e de investigação, concepção marcadamente autoritária, mas sujeito deles $^{42}$.

Pode-se dizer, por isso, que o princípio do Nemo tenetur se detegere constitui um direito do cidadão diante do poder estatal, limitando a atividade do Estado na busca da verdade no processo penal e, principalmente, se colocando como uma forma de proteção da dignidade humana:

Trata-se de uma decisão constitucional em favor do direito de personalidade do acusado; o princípio da verdade material é limitado visando proteger o núcleo absoluto do direito de personalidade do acusado (a sua dignidade humana) que estaria ameaçado diante de uma coação à auto-incriminação ${ }^{43}$.

\footnotetext{
41 AMARAL, Thiago Bottino do. A doutrina brasileira do direito ao silêncio: O STF e a conformação do sistema processual penal constitucional. In: PRADO, Geraldo (Org.); MALAN, Diogo (Org.). Processo Penal e Democracia: Estudos em Homenagem aos 20 Anos da Constituição da República de 1988. Rio de Janeiro: Lúmen Júris, 2009, p. 568.

42 QUEIJO, Maria Elizabeth. O Direito de não produzir prova contra si mesmo (o princípio nemo tenetur se detegere e suas decorrências no processo penal. São Paulo, Editora Saraiva, 2009. p. 1. De mesmo entendimento DIAS NETO, Theodomiro. O Direito ao silêncio: tratamento nos direitos alemão e norte-americano. Revista brasileira de ciências criminais. São Paulo, ano 5, n.19, p. 184: "Em países democráticos o acusado não se encontra mais em uma posição passiva de desproteção perante a imputação estatal. O acusado dispõe hoje de uma série de direitos constitucionais e processuais que lhe assegura possibilidade de intervir e influenciar no desenvolvimento de seu caso”. NUCCI, Guilherme de Souza. Provas no processo penal. São Paulo: Editora Revista dos Tribunais, 2009, p. 93, por sua vez, assegura que: "diante da garantia maior do Nemo tenetur se ipsum accusare, o acusado, sujeito da defesa, não tem obrigação nem ou dever de oferecer elementos de prova”.

43 DIAS NETO, Theodomiro. O Direito ao silêncio: tratamento nos direitos alemão e norteamericano. Revista brasileira de ciências criminais. São Paulo, ano 5, n.19, p. 187.
} 
É com base no que foi dito que Maria Elizabeth Queijo classifica esse direito como um direito negativo, exercido em face do Estado, conforme se observa de sua lição:

O nemo tenetur se detegere insere-se entre os direitos de primeira geração, que se traduzem por resistência ou oposição perante o Estado. Além de direito, é garantia da liberdade, em especial aquela de auto-determinação do acusado. Inclui-se entre as liberdades negativas: por meio dele assegura-se esfera de liberdade ao indivíduo que não deve sofrer vulnerações por parte do Estado ${ }^{44}$.

Além disso, é pacífico que esse direito insere-se no direito à intimidade e, por isso, constituiria um atributo da personalidade ${ }^{45}$. Nesse sentido é a lição de David Teixeira de Azevedo, para quem, também, o direito ao silêncio é parte do direito à intimidade. Seria permitir ao homem calar, não se expor, considerar seus juízos, sem que tenha qualquer interferência nessa esfera. É uma liberdade pública, direito oposto à autoridade pública, seja no campo da polícia judiciária, seja no campo da atividade jurisdicional ${ }^{46}$.

Por fim, antes de passarmos ao tópico seguinte, referente ao estudo do direito propriamente dito, deve-se ressaltar que o direito ao silêncio não é de interesse individual somente, mas também interesse coletivo, na medida em que é interesse do Estado o legítimo exercício da função jurisdicional, conforme se vê nos seguintes trechos:

44 QUEIJO, Maria Elizabeth. O Direito de não produzir prova contra si mesmo (o princípio nemo tenetur se detegere e suas decorrências no processo penal. São Paulo, Editora Saraiva, 2009. , p. 423. 45 MOURA, Maria Thereza Rocha de Assis; MORAES, Maurício Zanoide. Direito ao silêncio no interrogatório. Revista Brasileira de Ciências Criminais. São Paulo, ano 2, n. 6, abril/junho, 1994, p. 136.

46 "Há, desta forma, conteúdo escondido da personalidade, idéias, concepções de vida, juízos, emoções, desconhecidos da consciência, ou, se conhecidos, que nunca se pretendem sejam revelados. São as verdades, os fatos íntimos. [...]

Trata-se, a intimidade, como direito inerente à personalidade, direito oposto à autoridade pública, quer no campo da polícia judiciária, quer no da atividade jurisdicional.

Pertence o direito ao silêncio à intimidade, sendo manifestação de um fundamental aspecto das liberdades públicas. É necessário permitir ao homem calar, fechar-se em si mesmo, nos seus pensamentos e reflexões, não se expor, considerar seus juízos, posicionar-se axiologicamente perante as coisas, os homens, o universo”. (David Teixeira de Azevedo, p. 288) 
afinal, é também interesse da coletividade que o processo se desenvolva dentro das formas da lei, de tal forma que ninguém seja acusado ou condenado injustamente ${ }^{47}$.

Nesse contexto, podemos concluir que embora o direito ao silêncio possa constituir uma limitação à fiel reconstrução histórica, desejada idealmente, tal limitação é constitucionalmente lítica, na medida em que representa o necessário respeito às liberdades públicas e as verdades processualmente possíveis ${ }^{48}$.

Apesar de se tratar de direito de primeira geração, no qual a ênfase é o resguardo do indivíduo diante do Estado, há interesse público em sua proteção. É que o nemo tenetur se detegere insere-se no direito à defesa e na cláusula do devido processo legal. Repercute, via de conseqüência, na própria legitimação da jurisdição ${ }^{49}$.

\subsection{O princípio nemo tenetur se detegere no ordenamento jurídico brasileiro e seu status constitucional}

Em sua obra monográfica sobre o assunto, Maria Elizabeth Queijo ensina que o princípio em estudo passou a ser expresso no ordenamento jurídico brasileiro a partir da incorporação, ao direito interno, do Pacto Internacional dos Direitos Civis e Políticos ${ }^{50}$ e da Convenção Americana sobre Direitos Humanos ${ }^{51}$. Para a autora, a norma do artigo $5^{\circ}$, inciso LXIII da

47 DIAS NETO, Theodomiro. O Direito ao silêncio: tratamento nos direitos alemão e norteamericano. Revista brasileira de ciências criminais. São Paulo, ano 5, n.19, p. 183.

48 MOURA, Maria Thereza Rocha de Assis; MORAES, Maurício Zanoide. Direito ao silêncio no interrogatório. Revista Brasileira de Ciências Criminais. São Paulo, ano 2, n. 6, abril/junho, 1994, p. 141.

49 (QUEIJO, Maria Elizabeth. O Direito de não produzir prova contra si mesmo (o princípio nemo tenetur se detegere e suas decorrências no processo penal. São Paulo, Editora Saraiva, 2009. , p. 423) 50 O Pacto Internacional sobre Direitos Civis e Políticos, em seu artigo 14.3, dispõe que: "Toda pessoa acusada de um delito terá direito, em plena igualdade, às seguintes garantias mínimas:

g) a não ser obrigada a depor contra si mesma, nem a confessar-se culpada”.

51 A Convenção Americana sobre Direitos Humanos, em seu artigo 8.2 dispõe que: "2. Toda pessoa acusada de delito tem direito a que se presuma sua inocência enquanto não se comprove legalmente sua culpa. Durante o processo, toda pessoa tem direito, em plena igualdade, às seguintes garantias mínimas:

g) direito de não ser obrigado a depor contra si mesma, nem a declarar-se culpada”. 
Constituição Federal de 1988 teria tornado expresso tão somente o direito ao silêncio, uma decorrência desse princípio, e não o princípio em sua inteireza ${ }^{52}$.

Embora reconheça que há intenso debate doutrinário acerca do status das normas desses diplomas internacionais no direito interno, a autora se filia ao entendimento majoritário de que tem status constitucional, em virtude do disposto no art. $5^{\circ}$, § $2^{\circ}$ da Constituição Federal ${ }^{53}$.

Assim, integrando o rol das garantias desse artigo, o princípio nemo tenetur se detegere constitui um direito fundamental e, como tal, não poderia ser suprimido nem mesmo por emenda constitucional. Além disso, o reconhecimento de que constitui norma constitucional impõe que toda a legislação infraconstitucional seja interpretada em conformidade com o mesmo.

A melhor doutrina sobre o assunto acredita, entretanto, que o princípio em questão tem uma relação tão estreita com outros princípios constitucionalmente consagrados, que integraria o ordenamento jurídico brasileiro de qualquer forma, ainda que não expressamente. São os princípios da ampla defesa, do contraditório, do devido processo legal, da presunção de inocência e da dignidade humana. Antônio Scarance Fernandes, por exemplo, acentua que:

já era sensível a evolução da doutrina brasileira no sentido de extrair da cláusula de ampla defesa e de outros preceitos constitucionais, como o da presunção de

52 QUEIJO, Maria Elizabeth. O Direito de não produzir prova contra si mesmo (o princípio nemo tenetur se detegere e suas decorrências no processo penal. São Paulo, Editora Saraiva, 2009. queijo, p. 80

53 Art. $5^{\circ}$, § $2^{\circ}$ - "Os direitos e garantias expressos nesta Constituição não excluem outros decorrentes do regime e dos princípios por ela adotados, ou dos tratados internacionais em que a República Federativa do Brasil seja parte”. 
inocência, o princípio de que ninguém é obrigado a ser auto-incriminar, não podendo o suspeito ou o acusado ser forçado a produzir prova contra si mesmo ${ }^{54}$.

Em relação ao princípio da ampla defesa, o direito de não produzir prova contra si mesmo insere-se no aspecto da autodefesa, na medida em que tem o acusado o direito de fornecer subsídios à defesa técnica, mas, como é dispensável e renunciável, pode, também, como forma de defesa, preferir o silêncio ${ }^{55}$.

No mesmo sentido é a lição de Guilherme Souza Nucci, ao explicar que

O acusado (abrangendo a fase de suspeição e indiciamento) tem o direito fundamental de não produzir prova contra si mesmo, logo pode simplesmente silenciar quando se sentir pressionado a fazer ou narrar algo que não lhe seja conveniente ${ }^{56}$.

David Teixeira de Azevedo, por sua vez, ressalta que o princípio nemo tenetur se detegere se inseriria no aspecto negativo da ampla defesa, isto é, abrangeria a não produção de elementos probatórios de elevado risco ou potencialidade danosa à defesa do réu.

E resume, ressaltando a importância desse direito para uma atuação estratégica da defesa técnica: “A ampla defesa, destarte, pode ser

54 FERNANDES, Antonio Scarance. Processo penal constitucional. São Paulo: Editora Revista dos Tribunais, 1999, p. 261. Nessa mesma linha QUEIJO, Maria Elizabeth. O Direito de não produzir prova contra si mesmo (o princípio nemo tenetur se detegere e suas decorrências no processo penal. São Paulo, Editora Saraiva, 2009. Queijo, pag 69: "Antes de ser reconhecido expressamente no direito brasileiro, por meio das incorporações, ao direito interno, do Pacto Internacional dos Direitos Civis e Políticos e da convenção Americana sobre Direitos Humanos, já era possível extrair a incidência do nemo tenetur se detegere da cláusula do devido processo legal, do direito a ampla defesa, com relevo para o direito ao silencia, e do princípio da presunção da inocência” e TUCCI, Rogério Lauria. Direitos e garantias individuais no processo penal brasileiro, $2^{\mathrm{a}}$ Ed. São Paulo: Editora Revista dos Tribunais, 2004, p. 365: "Em nosso país, onde - como lembra ANTONIO SCARANCE FERNANDES, já se mostrava, também evolutivamente, sensível a orientação doutrinária no sentido de que, por força da amplitude da defesa, e de outros preceitos constitucionais, ninguém seria obrigado a auto-incriminarse, produzindo prova contra si mesmo".

55 Maria Thereza Rocha de Assis; MORAES, Maurício Zanoide. Direito ao silêncio no interrogatório. Revista Brasileira de Ciências Criminais. São Paulo, ano 2, n. 6, abril/junho, 1994, p. 137.

56 NUCCI, Guilherme de Souza. Provas no processo penal. São Paulo: Editora Revista dos Tribunais, 2009, pag. 69. 
conscientemente exercitada no silêncio do indiciado-réu, dentro de uma estrutura defensiva em que atuante o defensor técnico" ${ }^{57}$.

No mesmo sentido, é a lição de Maria Thereza de Assis Moura e Maurício Zanoide de Moraes: “À autodefesa soma-se a defesa técnica, na medida em que o silêncio pode resultar de orientação técnica do defensor, como alternativa e estratégia de defesa" ${ }^{58}$.

No tocante ao princípio do contraditório, pode-se dizer que o privilégio contra a auto-incriminação encontra-se particularizado neste ${ }^{59}$, conectando-se

diretamente um ao outro. É que, para o exercício do direito ao silêncio, ou seja, para se decidir quando é melhor produzir uma prova ou calar, é preciso que haja um contraditório real e efetivo, não bastando um conhecimento formal da acusação, mas uma noção exata do que está sendo imputado ao acusado. Assim é o preciso ensinamento de Maria Thereza de Assis Moura e Maurício Zanoide de Moraes, que, embora se refiram ao interrogando, não limitam esse direito ao momento do interrogatório ${ }^{60}$ :

O direito ao silêncio conecta-se à regra do contraditório real e efetivo, na medida em que, para o pleno exercício daquele, não é suficiente a ciência formal da acusação, mas a perfeita compreensão do imputado dos termos e da extensão e conseqüências da incriminação. Somente tendo a consciência perfeita do que lhe está sendo

57 AZEVEDO, David Teixeira de. O interrogatório do réu e o direito ao silêncio. Revista dos Tribunais, ano 81, agosto de 1992, vol. 682. p. 291.

58 MOURA, Maria Thereza Rocha de Assis; MORAES, Maurício Zanoide. Direito ao silêncio no interrogatório. Revista Brasileira de Ciências Criminais. São Paulo, ano 2, n. 6, abril/junho, 1994, p. 139.

59 TUCCI, Rogério Lauria. Direitos e garantias individuais no processo penal brasileiro, 2 ${ }^{\mathrm{a}}$ Ed. São Paulo: Editora Revista dos Tribunais, 2004, p. 368.

60 "Entendemos que definir o direito ao silêncio como sendo, unicamente, o direito de calar ante as perguntas da autoridade competente (policial ou judiciária), no momento do interrogatório, é impor-lhe uma limitação que não condiz com as origens do instituto". (MOURA, Maria Thereza Rocha de Assis; MORAES, Maurício Zanoide. Direito ao silêncio no interrogatório. Revista Brasileira de Ciências Criminais. São Paulo, ano 2, n. 6, abril/junho, 1994, p. 138) 
imputado poderá o interrogando saber se lhe é conveniente falar ou calar, produzir ou não determinada prova ou, ainda, praticar ou não atos lesivos à sua defesa ${ }^{61}$.

David Teixeira de Azevedo também fornece esclarecedora lição no que se refere à relação entre direito ao silêncio e o contraditório:

"É o contraditório entendido como a ciência bilateral dos atos processuais e a possibilidade efetiva, real, de contrariá-los. [...]

Possibilidade de contrariar a acusação nas diversas oportunidades processualmente oferecidas não significa dever de fazê-lo, sob pena de sanção. Há de ser concedida à defesa técnica os meios e modos de seu efetivo exercício, que serão avaliados segundo critérios de oportunidade, de conveniência, de utilidade, segundo uma visão de ampla defesa. [...]

O silêncio do réu no interrogatório, destarte é a voluntária "improdução" de prova, muita vez a significar o exercício da autodefesa ou a atuação estratégica da defesa técnica ${ }^{62}$.

A partir do que foi exposto em relação aos princípios da ampla defesa e contraditório, a relação entre o princípio do devido processo legal e do direito ao silêncio fica mais clara.

É que, segundo Maria Thereza de Assis Moura e Maurício Zanoide de Moraes, o direito ao silêncio: "Se insere na regra do devido processo legal, em suas garantias do exercício da ampla defesa, do contraditório e da presunção de inocência” ${ }^{33}$.

Já Maria Elizabeth Queijo explica que o processo não se limita a uma concatenação de atos processuais, tendentes a um provimento jurisdicional. As garantias do devido processo legal fazem com que seja mais que isso, impondo a realização do processo em contraditório, com o devido respeito aos direitos e

61 MOURA, Maria Thereza Rocha de Assis; MORAES, Maurício Zanoide. Direito ao silêncio no interrogatório. Revista Brasileira de Ciências Criminais. São Paulo, ano 2, n. 6, abril/junho, 1994, p. 138.

62 AZEVEDO, David Teixeira de. O interrogatório do réu e o direito ao silêncio. Revista dos Tribunais, ano 81, agosto de 1992, vol. 682, p. 289.

63 MOURA, Maria Thereza Rocha de Assis; MORAES, Maurício Zanoide. Direito ao silêncio no interrogatório. Revista Brasileira de Ciências Criminais. São Paulo, ano 2, n. 6, abril/junho, 1994, p. 137. 
garantias que possibilitam que as partes possam verdadeiramente influenciar o convencimento do julgador. E, assim, conclui pela inserção do princípio nemo tenetur se detegere entre essas garantias:

No aludido quadro de garantias, que compõe o devido processo legal, insere-se também o Nemo tenetur se detegere como um dos princípios que assegura a legitimação da jurisdição, dentro de uma visão ética do processo penal ${ }^{64}$.

Quanto ao princípio da presunção de inocência, Maria Tereza de Assis Moura e Maurício Zanoide de Moraes esclarecem que sua relação com o direito ao silêncio consiste na impossibilidade de que o exercício deste seja interpretado contrariamente a quem o exerce, valorando-o como indício de culpa $^{65}$.

Maria Elizabeth Queijo, em seu livro, destaca que o direito de não produzir prova contra si mesmo coaduna-se perfeitamente com o princípio da presunção de inocência, não sendo, assim, permitido que o acusado seja tratado como objeto de prova, pois seria o mesmo que admitir a possibilidade de obrigá-lo a cooperar na investigação dos fatos. A autora igualmente ressalta que a recusa do acusado em colaborar na persecução penal não pode ser interpretado desfavoravelmente a ele.

A autora, por fim, dá especial relevo à relação entre o direito ao silêncio e a proteção da dignidade humana. A dignidade humana seria algo inerente, essencial à natureza humana, não resultando, assim, de criação normativa. Com base, nisso, ela conclui:

64 QUEIJO, Maria Elizabeth. O Direito de não produzir prova contra si mesmo (o princípio nemo tenetur se detegere e suas decorrências no processo penal. São Paulo, Editora Saraiva, 2009. queijo, p. 72.

65 No mesmo sentido, TUCCI, Rogério Lauria. Direitos e garantias individuais no processo penal brasileiro, $2^{\mathrm{a}}$ Ed. São Paulo: Editora Revista dos Tribunais, 2004, p. 371: "E consequentemente, não pode importar em desfavorecimento do imputado, até porque consistiria inominado absurdo entenderse que o exercício de um direito, expresso na Lei das leis como fundamental do indivíduo, possa acarretar-lhe qualquer desvantagem”. 
Com relação ao Poder Público, em razão da tutela da dignidade humana, são inadmissíveis restrições injustificáveis ou desproporcionais dela. Também não são toleradas medidas que importem humilhações, discriminações ou perseguições.

Verifica-se, assim, que o Nemo tenetur se detegere está intimamente relacionado à proteção da dignidade humana ${ }^{66}$.

Theodomiro dias Neto também trata dessa estreita relação:

Em síntese, o direito ao silêncio é a expressão da proibição contra a autoincriminação, constitui um direito de personalidade, que por possuir a dignidade humana como seu núcleo, não está à disposição do legislador ${ }^{67}$.

Nesse sentido, para parte considerável da doutrina, o princípio nemo tenetur se detegere teria sido expressamente incluído, na forma que o entendemos atualmente, em nossa legislação, por meio de tratados internacionais. Porém, não fosse esse o caso, estaria ele, ainda que implicitamente, em nosso ordenamento jurídico, uma vez que está contido em outros preceitos constitucionais.

O autor Thiago Bottino, por sua vez, atribui a dimensão atual do princípio nemo tenetur se detegere a um ativismo judicial por parte do Supremo Tribunal Federal que se deu no sentido de reduzir a dicotomia entre o plano normativo constitucional - mais progressista e dedicado à proteção do indivíduo - e o infraconstitucional - correspondente ao paradigma autoritário.

Assim, em seu estudo, foi feita uma análise da interpretação do STF com relação ao seguinte dispositivo da Constituição Federal de 1988:

Art. $5^{\circ}$ Todos são iguais perante a lei, sem distinção de qualquer natureza, garantindo-se aos brasileiros e aos estrangeiros residentes no País a inviolabilidade do direito à vida, à liberdade, à igualdade, à segurança e à propriedade, nos termos seguintes:

66 QUEIJO, Maria Elizabeth. O Direito de não produzir prova contra si mesmo (o princípio nemo tenetur se detegere e suas decorrências no processo penal. São Paulo, Editora Saraiva, 2009. queijo, p. 79.

67 DIAS NETO, Theodomiro. O Direito ao silêncio: tratamento nos direitos alemão e norteamericano. Revista brasileira de ciências criminais. São Paulo, ano 5, n.19, p. 186. 
$[\ldots]$

LXIII - o preso será informado de seus direitos, entre os quais o de permanecer calado, sendo-lhe assegurada a assistência da família e de advogado;

Primeiramente observaram-se as decisões do STF que levaram a uma construção do significado do elemento normativo "preso"68 . Serviram como base os textos internacionais, incorporados pelo ordenamento jurídico brasileiro (Pacto Internacional de Direitos Civis e Políticos e Convenção Americana de Direitos Humanos) que se utilizam da expressão “toda pessoa acusada de um delito” no lugar do vacábulo “preso”.

\section{A conclusão a que se chegou é a de que a expressão "preso"} compreende:

qualquer indivíduo, preso ou solto, que seja suspeito, indiciado ou acusado em procedimento criminal, ou ainda à generalidade das pessoas diante de qualquer indagação por autoridade pública de cuja resposta possa advir imputação ao declarante de crime, ainda que em procedimento e foro diversos ${ }^{69}$.

$68 \mathrm{O}$ autor cita os seguintes julgados como paradigmáticos: Habeas Corpus $\mathrm{n}^{0}$ 68.742-3/DF, Pleno; $\mathrm{n}^{0}$ 68.929-9/SP, $1^{\text {a }}$ turma; $n^{\circ}$ 73.035-3/DF, Pleno e n ${ }^{0}$ 79.589-7/DF, Pleno.

69 AMARAL, Thiago Bottino do. O direito ao silêncio na jurisprudência do STF. São Paulo: Editora Campus/Elsevier, 2009, 205. No mesmo sentido, GRINOVER, Ada Pellegrini; FERNANDES, Antonio Scarance; GOMES FILHO, Antonio Magalhães. As nulidades no processo penal. $10^{\mathrm{a}}$ Ed. São Paulo: Editora Revista dos Tribunais, 2007, p 94: “A primeira observação é a de que, aludindo ao direito ao silêncio e à assistência do advogado para o preso, a Lei Maior denota simplesmente sua preocupação inicial com a pessoa capturada: a esta, mesmo fora e antes do interrogatório, são asseguradas as mencionadas garantias. Mas isto não pode, nem quer dizer que ao indiciado ou acusado que não esteja preso não seja estendida a mesma proteção, no momento maior da autodefesa, que é o interrogatório", , Maria Thereza Rocha de Assis; MORAES, Maurício Zanoide. Direito ao silêncio no interrogatório. Revista Brasileira de Ciências Criminais. São Paulo, ano 2, n. 6, abril/junho, 1994, p. 136: "certo é, ainda, que, embora a constituição em vigor tenha assegurado, no art.5 $5^{\circ}$, inc.LXIII, o direito ao silencia apenas ao preso, negar tal direito ao acusado que se encontra livre é ilógico, antejurídico e contrário ao nosso ordenamento" e TUCCI, Rogério Lauria. Direitos e garantias individuais no processo penal brasileiro, $2^{\mathrm{a}}$ Ed. São Paulo: Editora Revista dos Tribunais, 2004, p. 367: "acrescente-se que, como também de início ressaltado, esse direito, embora conferido expressamente ao preso, é reconhecido, segundo uniformizada orientação doutrinária e jurisprudencial, ao investigado, ao indiciado e ao acusado, ao ensejo do respectivo interrogatório”. 
Outro grupo de casos estudados ${ }^{70}$ determinava o alcance da locução “permanecer calado”. Diversas maneiras de interpretá-la foram consideradas variando de uma mera recusa de prestar depoimento até a abrangente permissão para fazer afirmações falsas quando inquirido.

A conclusão a que se chegou é que a expressão referida compreende:

a inexigibilidade de colaboração com a investigação (recusa de participar de reconstituição do crime, de fornecer material para exame grafotécnico ou de padrão vocal) e, inclusive, a possibilidade de opor-se à ação estatal que visa a sua responsabilização criminal (negando falsamente a prática do crime ou imputando falsamente sua autoria a outrem, cuja punibilidade esteja extinta ou, ainda, fornecendo material gráfico deliberadamente falso, visando a prejudicar as conclusões do exame pericial) $^{71}$.

Um último grupo de decisões analisadas tratava do desdobramento desse direito como mecanismo de atuação da defesa técnica, investigando as outras garantias que são indispensáveis à plena realização do direito de não se auto-incriminar. Mais especificamente, abrangia o direito da assistência do advogado no momento do interrogatório policial e judicial, do direito do indivíduo de ser expressamente informado da garantia de não se autoincriminar, e a expressão "seus direitos”.

Gradualmente, chegou-se à seguinte conclusão quanto à expressão "assegurada assistência de advogado":

Que o preso não tem o direito de que o Estado assegure assistência de advogado no momento de sua prisão, nem no momento de seu interrogatório policial; a assitência de advogado é obrigatória, porém, antes e durante o interrogatório judicial "mas por força da lei infraconstitucional $^{72}$.

No tocante à expressão “será informado”, o conteúdo a ela dado é:

$70 \mathrm{O}$ autor cita os seguintes julgados como paradigmáticos:Habeas Corpus $n^{\circ}$ 68.742-3/DF, Pleno; Habeas Corpus $n^{0}$ 69.026-2/DF, $1^{\text {a }}$ Turma; Habeas Corpus $n^{0}$ 80.616-3/SP, $2^{\mathrm{a}}$ turma; Habeas Corpus $n^{0}$ 83.960-6/RS, 1a turma.

71 AMARAL, Thiago Bottino do. O direito ao silêncio na jurisprudência do STF. São Paulo: Editora Campus/Elsevier, 2009, p. 205.

72 AMARAL, Thiago Bottino do. O direito ao silêncio na jurisprudência do STF. São Paulo: Editora Campus/Elsevier, 2009, p. 205 
que o indivíduo deve ser infornado de sua garantia de não se auto-incriminar desde o momento em que tiver sua liberdade cerceada[...] cerceada, constituindo nulidade absoluta a inobservância dessa regra ${ }^{73}$.

Por último, com relação à expressão "seus direitos”, a abrangência da mesma foi assim exposta:

“que o exercício dessa garantia constitucional não pode ensejar nenhum tipo de presunção que lhe seja prejudicial, nem fundamentar qualquer tipo de tratamento

mais gravoso, nem tampouco justificar sua segregação cautelar ao argumento de que o indivíduo não está colaborando com a investigação ou instrução processual”74.

Dessa forma, na visão de Thiago Bottino, é a interpretação dada ao artigo $5^{\circ}$, inciso LXIII da Constituição Federal pelo Supremo Tribunal Federal que nos fornece a real dimensão do princípio nemo tenetur se detegere.

Em suma, pode-se entender que a sede legal da garantia contra a autoincriminação são os tratados internacionais a que nos referimos e o artigo $5^{\circ}$, LXIII da Constituição Federal, levando-se em conta a jurisprudência do Supremo Tribunal Federal.

\subsection{Decorrências do princípio nemo tenetur se detegere}

Uma vez entendido o contexto em que se insere o privilégio contra a auto-incriminação e vista sua sede legal no ordenamento jurídico brasileiro, é preciso entender em que consiste, concretamente, a referida garantia.

A primeira decorrência do princípio nemo tenetur se detegere se confunde com o seu próprio conteúdo. É a garantia que o acusado tem de não

73 AMARAL, Thiago Bottino do. O direito ao silêncio na jurisprudência do STF. São Paulo: Editora Campus/Elsevier, 2009, p. 205

74 AMARAL, Thiago Bottino do. O direito ao silêncio na jurisprudência do STF. São Paulo: Editora Campus/Elsevier, 2009, p. 205. 
ser compelido a se auto-incriminar. Tal entendimento é perfilhado por Maria Thereza de Assis Moura e Maurício Zanoide de Moraes:

Entendemos que definir o direito ao silêncio como sendo, unicamente, o direito de calar ante as perguntas da autoridade competente (policial ou judiciária), no momento do interrogatório, é impor-lhe uma limitação que não condiz com as origens do instituto ${ }^{75}$.

Maria Elizabeth Queijo, ao fazer essa análise, explica, primeiramente, as decorrências desse princípio no interrogatório, em que foi inicialmente reconhecido, e após, volta sua análise às decorrências desse princípio no que se refere às provas que dependem da cooperação do acusado, de maior interesse para o presente estudo.

Ao tratar do princípio Nemo tenetur se detegere no interrogatório, a autora esclarece que o referido direito se aplica a qualquer interrogatório realizado durante a persecução penal, sejam as declarações e depoimentos colhidos por autoridades do Poder Executivo, Legislativo ou Judiciário. Aplica-se, também, como visto no tópico anterior, ao acusado preso ou solto. A autora expressamente inclui a pessoa jurídica, os suspeitos e as testemunhas como protegidos por esse direito ${ }^{76}$.

Em consonância com a melhor doutrina, dá especial relevo à necessidade de advertência ao acusado quanto a esse direito, para que esteja ciente de que pode silenciar quando assim lhe for mais conveniente, sem que haja qualquer prejuízo para sua defesa ${ }^{77}$.

75 MOURA, Maria Thereza Rocha de Assis; MORAES, Maurício Zanoide. Direito ao silêncio no interrogatório. Revista Brasileira de Ciências Criminais. São Paulo, ano 2, n. 6, abril/junho, 1994, p. 138.

76 No mesmo sentido, DIAS NETO, Theodomiro. O Direito ao silêncio: tratamento nos direitos alemão e norte-americano. Revista brasileira de ciências criminais. São Paulo, ano 5, n.19, p. 188/189. 77 QUEIJO, Maria Elizabeth. O Direito de não produzir prova contra si mesmo (o princípio nemo tenetur se detegere e suas decorrências no processo penal. São Paulo, Editora Saraiva, 2009. queijo, p. 425. 
Nesse mesmo sentido, é a lição de Theodomiro Dias Neto, ao tratar do dever de instrução do direito ao silêncio:

Do caráter prioritário que o ordenamento jurídico destina à proteção do direito ao silêncio resulta a obrigação estatal de instruir, ou seja, de informar sobre tal direito. Trata-se de um dever de assistência, de tutela do Estado [...] O legislador decidiu neste caso por não pressupor o conhecimento do direito e visou assegurar, com o dever de instrução, que ninguém, por ignorância da lei, sinta-se psiquicamente pressionado a contribuir ativamente com o Estado através de declarações auto-incriminatórias ${ }^{78}$.

Maria Elizabeth traz, ainda, como decorrências, a não admissão de consignação das perguntas em que o acusado fez uso do direito ao silêncio; a impossibilidade de valoração desse silêncio, sendo simples ausência de resposta e opção por não formar elementos a seu favor ${ }^{79}$; a vedação de técnicas de interrogatório que se utilizem de perguntas sugestivas, capciosas, de meios enganosos, de tortura, etc.; a inexistência do dever de dizer a verdade, sendo defesa a imposição de juramento ao acusado e sanções a este quando mentir; e, por fim, a inexistência do dever de comparecimento.

Theodomiro Dias Neto, ao tratar do direito alemão, também aponta métodos de interrogatórios não admitidos, por se estar diante de um ordenamento jurídico que garante o direito contra a auto-incriminação. Entre outros, o autor cita todas as formas de influência física, todas as formas de influência psíquica e medidas que prejudiquem a memória ou capacidade de compreensão do acusado ${ }^{80}$.

78 DIAS NETO, Theodomiro. O Direito ao silêncio: tratamento nos direitos alemão e norteamericano. Revista brasileira de ciências criminais. São Paulo, ano 5, n.19, p. 188.

79 De mesmo entendimento é a lição de David Teixeira de Azevedo: "Com efeito, interpretar o silêncio em prejuíco do réu significa negar o princípio da presunção de inocência, mentir o contraditório, o direito e a garantia à ampla defesa, além de desrespeito à intimidade ao membro do corpo social”. (AZEVEDO, David Teixeira de. O interrogatório do réu e o direito ao silêncio. Revista dos Tribunais, ano 81, agosto de 1992, vol. 682.

, p. 291)

80 DIAS NETO, Theodomiro. O Direito ao silêncio: tratamento nos direitos alemão e norteamericano. Revista brasileira de ciências criminais. São Paulo, ano 5, n.19, p. 188. 
Maria Elizabeth defende que, em virtude da adoção desse princípio de forma irrestrita em nosso ordenamento jurídico, estariam revogados os artigos 186, 191, 198 (parcialmente) e 260 do Código de Processo Penal. Esse entendimento foi parcialmente adotado pelo legislador brasileiro e os artigos 186 e 191 do CPP foram expressamente alterados pela Lei 10.792/2003. Os artigos 198 e 260, entretanto, se mantêm com a redação considerada inconstitucional pela autora.

Maria Thereza de Assis Moura e Maurício Zanoide de Moraes, ao tratarem das limitações do direito ao silêncio (que não se dá quanto à qualificação do acusado procedida no interrogatório) compartilham do mesmo entendimento no que se refere ao artigo 186 e 198 do CPP, não modificado pelo legislador brasileiro:

Esta limitação extensiva é a única constitucionalmente aceitável. As limitações decorrentes da aplicação dos arts. 186, $2^{\text {a }}$ parte e 198, ambos do CPP, são inconstitucionais, porque limitam o silêncio até mesmo nos momentos em que seu exercício é garantido pelo art. $5^{\circ}$, LXIII, da $\mathrm{CF}^{81}$.

E complementam, explicando que:

Não mais prevalecem, a partir da promulgação da CF/88, por representarem uma limitação a direito público subjetivo constitucional. Insista-se, lei inferior (CPP) não pode limitar o que lei superior (CF) não quis fosse limitado ${ }^{82}$.

Dessa forma, pode-se reconhecer que o referido princípio foi devidamente adotado em alguns artigos do Código de Processo Penal, como o artigo 186, CPP, cuja redação era a seguinte:

81 MOURA, Maria Thereza Rocha de Assis; MORAES, Maurício Zanoide. Direito ao silêncio no interrogatório. Revista Brasileira de Ciências Criminais. São Paulo, ano 2, n. 6, abril/junho, 1994, p. 139.

82 MOURA, Maria Thereza Rocha de Assis; MORAES, Maurício Zanoide. Direito ao silêncio no interrogatório. Revista Brasileira de Ciências Criminais. São Paulo, ano 2, n. 6, abril/junho, 1994, p. 139. 
Art. 186. Antes de iniciar o interrogatório, o juiz observará ao réu que, embora não esteja obrigado a responder às perguntas que lhe forem formuladas, o seu silêncio poderá ser interpretado em prejuízo da própria defesa.

Atualmente, a redação, dada pela Lei n ${ }^{0}$ 10.792/2003, é a seguinte:

Art. 186. Depois de devidamente qualificado e cientificado do inteiro teor da acusação, o acusado será informado pelo juiz, antes de iniciar o interrogatório, do seu direito de permanecer calado e de não responder perguntas que lhe forem formuladas.

Parágrafo único. O silêncio, que não importará em confissão, não poderá ser interpretado em prejuízo da defesa.

O mesmo se deu com o artigo 198, CPP, cuja redação consistia em: “Ar. 191. Consignar-se-ão as perguntas que o réu deixar de responder e as razões que invocar para não fazê-lo”.

Atualmente, entretanto, a redação atual, igualmente dada pela Lei 10.792/2003, é "Havendo mais de um acusado, serão interrogados separadamente”. Assim, alterou-se completamente a redação do referido artigo.

Ao contrário dos dois artigos mencionados acima, o artigo 198, CPP não foi expressamente alterado, contando, ainda, com a seguinte redação: “O silêncio do acusado não importará confissão, mas poderá constituir elemento para a formação do convencimento do juiz”.

O referido artigo é flagrantemente inconstitucional, por que, sendo o direito ao silêncio um direito constitucionalmente assegurado, deve ser entendido o seu exercício tão-somente como uma não produção de prova. Permitir que constitua elemento para a formação do convencimento do juiz, eventualmente sendo fator desfavorável ao réu, é uma verdadeira violação da presunção de inocência.

Assim como o dispositivo legal acima mencionado, o artigo 260, СРP também não foi alterado, constando, ainda a seguinte redação: 
Art. 260. Se o acusado não atender à intimação para o interrogatório, reconhecimento ou qualquer outro ato que, sem ele, não possa ser realizado, a autoridade poderá mandar conduzi-lo à sua presença.

Parágrafo único. O mandado conterá, além da ordem de condução, os requisitos mencionados no art. 352, no que Ihe for aplicável”.

Também questionável a sua constitucionalidade, porque parte da doutrina, como Maria Elizabeth Queijo, acredita que não há o dever de comparecimento por parte do réu.

O projeto de lei de reforma global do CPP ora em tramitação no Senado Federal (PLS nº. 156/09), embora não vigore ainda, é um projeto de grande importância, principalmente pelo notório saber dos juristas que participam de sua elaboração. O referido projeto traz alguns artigos que merecem ser expressamente mencionados, por consagrarem o direito ao silêncio:

Art. 65. Antes do interrogatório, o investigado ou acusado será informado: I - do inteiro teor dos fatos que lhe são imputados ou, estando ainda na fase de investigação, dos indícios então existentes;

II - de que poderá entrevistar-se, em local reservado, com o seu defensor; III - de que as suas declarações poderão eventualmente ser utilizadas em desfavor de sua defesa; IV - do direito de permanecer em silêncio, não estando obrigado a responder a uma ou mais perguntas em particular, ou todas que lhe forem formuladas; $\mathrm{V}$ - de que o silêncio não importará confissão, nem poderá ser interpretado em prejuízo de sua defesa.

Parágrafo único. Em relação à parte final do inciso I deste artigo, a autoridade não está obrigada a revelar as fontes de prova já identificadas ou a linha de investigaçãoadotada.

Art. 380. Durante os debates as partes não poderão, sob pena de nulidade, fazer referências:

I - aos fundamentos da decisão de pronúncia ou das decisões posteriores que julgaram admissível a acusação, aos motivos determinantes do uso de algemas como argumento de autoridade que beneficiem ou prejudiquem o acusado;

II - ao silêncio do acusado ou à ausência de interrogatório por falta de requerimento, em seu prejuízo.

III - aos depoimentos prestados na fase de investigação criminal, ressalvada a prova antecipada.

Art. 534. O preso será informado de seus direitos, entre os quais o de: 
I - permanecer em silêncio;

II - saber a identificação dos responsáveis por sua prisão;

III - receber um exemplar do mandado judicial, salvo em flagrante delito;

IV - fazer contato telefônico com familiar ou outra pessoa indicada, tão logo

seja apresentado à autoridade policial;

$\mathrm{V}$ - ser assistido por um advogado de sua livre escolha ou defensor público;

VI - ser recolhido em local separado dos presos com condenação definitiva.

Parágrafo único. As informações relativas aos direitos previstos nos incisos I

e V do caput deste artigo constarão, por escrito, de todos os atos de investigação e

de instrução criminal que requeiram a participação do investigado ou acusado, sob

pena de nulidade.

Quanto às decorrências do princípio nemo tenetur se detegere no tocante às provas que dependem de colaboração do acusado, Maria Elizabeth Queijo observa três grandes decorrências: a inexistência do dever de colaboração (a regra deve ser a de que a acusação deve buscar provas que independam da colaboração do acusado), a impossibilidade de se extraírem conseqüências da recusa do acusado em submeter-se a determinada prova $^{83}$, e a inexistência do dever de comparecimento.

Assim, o direito de não produzir prova contra si mesmo impõe que a recusa do acusado em colaborar com a produção de provas não possa configurar crime de desobediência, nem admite execução coercitiva. A autora adverte sobre a existência de exceções a essa decorrência.

Há, igualmente, o dever por parte da autoridade de advertir o acusado acerca de sua possibilidade de recusar à produção da prova. E, além dessa obrigatoriedade, como forma de evitar que o acusado colabore com a acusação

83 Isto é, não constitui indício de culpabilidade e não configura delito de desobediência (ou qualquer outro delito). Para a autora, se houvesse lei prevendo exceções, a única exceção à recusa do acusado seria execução coercitiva, quando não se tratasse de intervenção corporal invasiva ou colaboração ativa do acusado. QUEIJO, Maria Elizabeth. O Direito de não produzir prova contra si mesmo (o princípio nemo tenetur se detegere e suas decorrências no processo penal. São Paulo, Editora Saraiva, 2009. , p. 432. 
contra sua vontade, há uma série de requisitos para que seja válido o seu consentimento em cooperar ${ }^{84}$.

Maria Elizabeth Queijo, não considera suficiente o critério segundo o qual o acusado não está obrigado a colaborar em provas que dependam de sua participação ativa, mas estaria obrigado a tolerar aquelas que exigiriam sua participação de forma passiva, devendo ser usado o princípio da proporcionalidade para solucionar a questão. E, em uma tentativa de compatibilizar o direito em questão com a viabilidade da persecução penal, afirma que esse direito não é absoluto, comportando situações em que há excepcionais restrições ao mesmo.

Tais restrições somente poderiam ser efetivadas se previstas em lei, estrita e prévia, que atendesse ao princípio da proporcionalidade sob pena de inconstitucionalidade. Ainda assim, somente se admitiriam hipóteses em que a restrição fosse: indispensável; de forma menos gravosa possível; adequada e idônea para a produção da prova pretendida, incidindo sobre pessoa contra a qual existam indícios de autoria e participação em infração penal; razoável, considerando a gravidade do crime e a força dos indícios existentes; comedida,

84 Maria Elizabeth Queijo enumera, como alguns desses requisitos, os seguintes: disponibilidade do direito (não se pode, assim, consentir com intervenções corporais que envolvam perigo para sua vida e saúde); a capacidade civil para dispor; o consentimento não pode ser manifestado posteriormente, como ratificação; o consentimento deverá ser expresso e manifestado em relação a uma situação específica; e, por fim, deverá ser fruto de vontade livre, sem vícios de consentimento. (QUEIJO, Maria Elizabeth. O Direito de não produzir prova contra si mesmo (o princípio nemo tenetur se detegere e suas decorrências no processo penal. São Paulo, Editora Saraiva, 2009. , p. 429) Em sentido contrário, a jurisprudência americana, conforme Theodomiro Dias Neto, dispõe que "a posição da jurisprudência tem sido no sentido de que a renúncia dos direitos não deve ser necessariamente expressa. Embora uma declaração expressa seja "forte evidência da validade de uma renúncia, esta não é nem necessária, nem suficiente: A questão não está na forma, mas se o acusado de fato renunciou aos direitos delineados em Miranda de forma consciente e voluntária” (North Carolina v. Butler)”. (DIAS NETO, Theodomiro. O Direito ao silêncio: tratamento nos direitos alemão e norte-americano. Revista brasileira de ciências criminais. São Paulo, ano 5, n.19, p. 201). 
devendo respeitar o núcleo essencial do princípio; submetida ao controle judicial $^{85}$; e observadora estrita da saúde e dignidade do acusado.

Quanto às conseqüências da violação do princípio nemo tenetur se detegere, a autora também faz a análise primeira do interrogatório e, depois, das provas que dependem da cooperação do acusado.

No que se refere ao interrogatório (seja judicial, seja policial), se houver confissão por falta ou deficiência do dever de advertência acerca do direito ao silêncio, ou pela utilização de métodos de interrogatório vedados, a prova será considerada ilícita, inadmissível. O mesmo em relação às provas subseqüentes, ou, ainda, à denúncia, se nela baseada. Se houver consignação das perguntas não respondidas e das razões pelas quais o acusado silenciou, tais elementos constituem provas ilícitas, devendo ser suprimidos dos autos. Se, por fim, houver valoração do silêncio, a decisão judicial será reputada nula ${ }^{86}$.

Em seu estudo sobre os princípios do processo penal, Américo Bedê Junior e Gustavo Senna questionam-se acerca da conseqüência para a omissão do juiz em alertar o réu sobre seu direito de permanecer calado, se isso constituiria uma ilicitude e concluem:

Parece-nos que, como existe dispositivo expresso art. 186 do CPP e art. 5, LXIII, da $\mathrm{CF}$ ), o argumento de que ninguém pode alegar o desconhecimento do direito cede em

85 Se implicarem em intervenção corporal no acusado, deverão ser determinadas por decisão judicial devidamente motivada; senão, o controle judicial pode ser feito a posteriori. (QUEIJO, Maria Elizabeth. O Direito de não produzir prova contra si mesmo (o princípio nemo tenetur se detegere e suas decorrências no processo penal. São Paulo, Editora Saraiva, 2009. , p. 430)

86 Maria Thereza Assis Moura e Mauricio Zanoide de Moraes esclarecem que: "o silêncio não pode ser objeto de valoração jurisdicional, porque não constitui prova, no sentido jurídico do termo. Significa, tão-somente, que o imputado optou, no exercício de sua autodefesa, por deixar de fornecer sua versão pessoal dos fatos que são objeto de prova”. E prosseguem: “A prática, porém, está a demonstrar que a crença de que o imputado possui o dever de colaborar na busca da verdade, embora infundada, tem impedido o pleno exercício do direito ao silêncio. Isto porque sua recusa é vista como verdadeiro indício de culpabilidade, acreditando alguns que, se o interrogado é inocente, não há motivo para impedir a reconstrução da verdade 'real'”. (MOURA, Maria Thereza Rocha de Assis; MORAES, Maurício Zanoide. Direito ao silêncio no interrogatório. Revista Brasileira de Ciências Criminais. São Paulo, ano 2, n. 6, abril/junho, 1994, p. 139/140). 
face de norma específica, e a omissão provoca, invariavelmente, a nulidade da confissão ${ }^{87}$.

\author{
Ada Pellegrini Grinover, Antonio Scarance Fernandes e Antonio \\ Magalhães Gomes Filho, tratando das nulidades do processo penal, são \\ categóricos ao afirmar que:
}

Neste ponto, o vício maior do interrogatório é a falta de informação sobre o direito de o indiciado ou o acusado de permanecer calado. A doutrina estrangeira, há mais tempo afeita à garantia do pleno direito ao silêncio, assentou que o interrogatório do acusado ou mesmo suas declarações espontâneas perante o órgão estatal somente são válidos desde que tenha havido informação sobre a faculdade de calar. Nem pode ser diversamente, sob pena de restringir o direito ao silêncio e a correspondente informação a meras fórmulas, vazias de conteúdo.

Resulta daí que a ausência de informação implica a nulidade do interrogatório, a qual, por sua vez, pode assumir duas dimensões: a mais grave, consubstanciada na nulidade de todo o processo, a partir do interrogatório, se, no caso, o ato viciado redundou no sacrifício da autodefesa e, conseqüentemente da defesa como um todo. Ou, na dimensão mais moderada, pela invalidade do interrogatório, com sua necessária repetição, mas sem que os atos sucessivos fiquem contaminados, se se verificar que o conteúdo das declarações não prejudicou a defesa como um todo e os atos sucessivos $^{88}$.

\title{
Endossando esse entendimento, Maria Thereza de Assis Moura e
}

\section{Maurício Zanoide de Moraes:}

Destarte, todos os atos produzidos após 5.10.88, sem a observância do direito ao silêncio, são absolutamente nulos, por contrariarem norma de teor constitucional. Eventual argumentação de legalidade destes atos, que tenha por fundamento a aplicação das normas processuais já apontadas, não pode prevalecer, por que de norma ordinária infraconstitucional não pode nascer ato juridicamente válido ${ }^{89}$.

Theodomiro Dias Neto, ao tratar da utilização de métodos de interrogatório proibidos no direito alemão, explica que:

87 BEDÊ JÚNIOR, Américo; SENNA, Gustavo. Princípios do processo penal. São Paulo: Editora Revista dos Tribunais, 2009, p. 39.

88 GRINOVER, Ada Pellegrini; FERNANDES, Antonio Scarance; GOMES FILHO, Antonio Magalhães. As nulidades no processo penal. 10 ${ }^{\mathrm{a}}$ Ed. São Paulo: Editora Revista dos Tribunais, 2007, p. 96.

89 MOURA, Maria Thereza Rocha de Assis; MORAES, Maurício Zanoide. Direito ao silêncio no interrogatório. Revista Brasileira de Ciências Criminais. São Paulo, ano 2, n. 6, abril/junho, 1994, p. 139. 
Uma violação deste artigo ocorrerá toda vez que a liberdade de decisão voluntária e de atuação da vontade do acusado for violada em virtude de uma coerção não admissível pelo direito processual penal. Nesses casos, a declaração será considerada inválida como meio de prova ${ }^{90}$.

Quanto ao direito americano, o mesmo autor enumera as Miranda Rules $^{91}$, e entre elas, consta a seguinte, na mesma linha do direito brasileiro:

(9) Qualquer declaração obtida em violação a estas normas não será admitida como meio de prova, independentemente da confissão ser total ou parcial, ou de ser inculpatória ou, alegadamente, exculpatória ${ }^{92}$.

De mesma natureza são às decorrências da violação ao direito em questão quando se trata das provas que dependem de cooperação do acusado. Isto é, são ilícitas as provas colhidas e aquelas delas derivadas. Admite-se, entretanto, a prova ilícita se seu resultado for pro reo, permitindo-se sua permanência nos autos e sua valoração.

Em conclusão, viu-se o contexto em que se insere o princípio Nemo tenetur se detegere, estudou-se sua posição no ordenamento jurídico brasileiro e, por fim, entendemos suas decorrências, seja no interrogatório do acusado, seja nas provas que dependem de sua cooperação. Por fim, diante de sua importância como direito fundamental, constitucionalmente estabelecido, ficou claro que qualquer prova obtida mediante sua violação deve ser reputada nula, bem como todas as outras desta primeira derivada.

90 DIAS NETO, Theodomiro. O Direito ao silêncio: tratamento nos direitos alemão e norteamericano. Revista brasileira de ciências criminais. São Paulo, ano 5, n.19, p. 188.

91 São regras, definidas no caso Miranda v Arizona, que deveriam ser seguidas pela polícia em todos os casos envolvendo interrogatório sob custódia. Essas regras acabaram por ser, posteriormente, flexibilizadas.

92 DIAS NETO, Theodomiro. O Direito ao silêncio: tratamento nos direitos alemão e norteamericano. Revista brasileira de ciências criminais. São Paulo, ano 5, n.19, p. 198. 


\section{CRÍTICA AO CRIME DE EMBRIAGUEZ AO VOLANTE}

\subsection{A "administrativização" do Direito Penal e o tipo objetivo do crime de embriaguez ao volante.}

Antes de iniciar o estudo do tipo penal propriamente dito, é importante ressaltar que a adoção de uma política criminal rigorosa com relação à direção embriagada tem grande valor para a sociedade. Não se pode ignorar o número de acidentes e vítimas fatais nas estradas. Por isso, é legítimo que o Direito Penal desempenhe algum papel na tentativa de evitar esse comportamento, principalmente por estar em questão valiosos bens jurídicos, como a vida e a integridade física.

Entretanto, o direito penal como é hoje, considerando seus princípios fundamentais, é, igualmente, uma conquista da sociedade. Por isso, o que se critica é a forma de criminalizar a embriaguez ao volante, tendo em vista que o legislador vem adotando formas inconstitucionais de fazê-lo.

Feita a ressalva inicial, passemos à análise desta infração penal.

A segurança viária sempre foi uma preocupação do legislador brasileiro. Segundo Luiz Flávio Gomes ${ }^{93}$, antes do Código de Trânsito de 1997, a embriaguez ao volante era punida por se subsumir ao artigo 34 do Decreto-Lei n. 3.688 de 1941, Lei das Contravenções Penais:

Art. 34. Dirigir veículos na via pública, ou embarcações em águas públicas, pondo em perigo a segurança alheia:

Pena - prisão simples, de quinze dias a três meses, ou multa, de trezentos mil réis a dois contos de réis.

93 GOMES, Luiz Flávio et all.. Comentários às Reformas do Código de Processo Penal e da Lei de Trânsito. São Paulo: Editora Revista dos Tribunais, 2008, p. 374. 
Nessa época, a doutrina dominante era no sentido de que se estava diante de infração de perigo abstrato, de forma que se presumia o perigo de forma absoluta, não podendo ser feita prova em contrário.

A partir de 1997, com o advento do Código de Trânsito Brasileiro, o delito de embriaguez ao volante passou a ser tipificado pelo artigo 306 do mesmo, cuja redação era a seguinte:

Art. 306. Conduzir veículo automotor, na via pública, sob a influência de álcool ou substância de efeitos análogos, expondo a dano potencial a incolumidade de outrem.

Penas - detenção, de 6 (seis) meses a 3 (três) anos, multa e suspensão ou proibição de se obter a permissão ou a habilitação para dirigir veículo automotor.

Com essa nova redação, o crime de embriaguez ao volante deixou de ser crime de perigo abstrato, passando a ser crime de perigo concreto, isto é, pela literalidade da lei, exigia-se a demonstração de que teria ocorrido um risco, uma situação de perigo para uma determinada pessoa. Entretanto, o entendimento majoritário foi no sentido de que, embora de perigo concreto, não precisava ser demonstrado o risco a uma pessoa determinada, mas, tãosomente, uma direção, o que já se mostrava suficiente para diminuir a segurança no tráfego.

Recentemente, o delito de embriaguez ao volante sofreu alteração por parte da Lei 11.705/2008, sem, entretanto, haver modificação na pena prevista. Sua redação atual é a seguinte:

Art. 306. Conduzir veículo automotor, na via pública, estando com concentração de álcool por litro de sangue igual ou superior a 6 (seis) decigramas, ou sob a influência de qualquer outra substância psicoativa que determine dependência:

Penas - detenção, de seis meses a três anos, multa e suspensão ou proibição de se obter a permissão ou a habilitação para dirigir veículo automotor.

Parágrafo único. O Poder Executivo federal estipulará a equivalência entre distintos testes de alcoolemia, para efeito de caracterização do crime tipificado neste artigo. 
As modificações foram recebidas com ressalvas pela doutrina e, principalmente, com controvertida aplicação pelos tribunais.

A partir da leitura do tipo penal em questão, observa-se que há nele duas condutas incriminadas. A primeira seria conduzir veículo automotor, na via pública, estando com concentração de álcool por litro de sangue igual ou superior a 6 (seis) decigramas; a segunda seria conduzir veículo automotor, na via pública, sob a influência de qualquer outra substância psicoativa que determine dependência.

No livro "Comentários às reformas do código de processo penal e da lei de trânsito”, Luiz Flávio Gomes observa que somente em relação à segunda conduta haveria a exigência expressa da elementar "estar sob influência" da substância, manifestada na direção anormal, colocando em risco a segurança viária $^{94}$.

Com isso, passou-se a discutir qual a natureza do crime em questão, se de delito de perigo abstrato ou delito de perigo concreto. Ângelo Roberto Ilha da Silva define ambos os tipos de crime:

Os crimes de perigo concreto são aqueles segundo os quais, para o aperfeiçoamento do tipo, exige-se a verificação efetiva do perigo, em que este constitui elemento do tipo e deve ser constatado caso a caso, sendo que, nas hipóteses em que a descrição típica não seja taxativa, a infração de perigo deve assumir também a forma de perigo concreto, ainda que não indicado no modelo legal.

Os crimes de perigo abstrato ou presumido, segundo a doutrina majoritária, são aqueles cujo perigo é ínsito na conduta e presumido juris et de jure, assim definido pelo legislador “a priori". Enquanto nos crimes de perigo concreto o perigo constituielemento do tipo, nos modelos de perigo abstrato constitui tão-só sua motivação ${ }^{95}$.

94 GOMES, Luiz Flávio et all.. Comentários às Reformas do Código de Processo Penal e da Lei de Trânsito. São Paulo: Editora Revista dos Tribunais, 2008, p. 375/376.

95 SILVA, Ângelo Roberto Ilha da. Dos crimes de perigo abstrato em face da Constituição. São Paulo: Editora Revista dos Tribunais, 2003, p. 149. 
A doutrina dominante considera que uma interpretação literal do referido dispositivo leve à consideração de que consiste em um delito de perigo abstrato, embora expressiva parte dela não se conforme com tal interpretação, em virtude do princípio constitucional implícito da ofensividade.

Dessa forma se manifesta Cássio Benvenutti de Castro:

A classificação da infração assumiu contornos mais rigorosos. Tornou-se desnecessária a prova da exposição do perigo, facilitando o sucesso da pretensão acusatória, desde que observado o limite objetivo de alcoolemia cunhado na reforma.

Privilegiando o postulado da ofensividade, vetor da inferência mínima criminal na ordem jurídica do Estado Democrático de Direito, há estudos que insistem pela natureza concreta do perigo tipificado no art. 306 , sob pena de inconstitucionalidade ${ }^{96}$.

Da mesma forma, o autor Renato Marcão, adotando interpretação literal do dispositivo legal, acentua que não é necessário qualquer tipo de anormalidade, sendo o crime de perigo abstrato: "Não se exige mais um conduzir anormal, manobras perigosas, que exponham a dano efetivo a incolumidade de outrem. [...] O crime, agora, é de perigo abstrato” ${ }^{97}$.

Parte da jurisprudência também adotou esse entendimento, o que se exemplifica pelas duas ementas de julgados da $6^{\text {a }}$ Câmara Criminal do Tribunal de Justiça do Estado do Rio de Janeiro:

HABEAS CORPUS. EMBRIAGUEZ AO VOLANTE. ETILÔMETRO. ARTIGO 306 DA LEI 9.503/97. ALEGAÇÃO DE INÉPCIA DA DENÚNCIA. PEDIDO DE REJEIÇÃO. NÃO DESCRIÇÃO DE DIREÇÃO ANORMAL. DESNECESSIDADE. CRIME DE PERIGO ABSTRATO. PRECEDENTES NA DOUTRINA.POR MENOR QUE SEJA A QUANTIDADE DE SANGUE DO MOTORISTA JÁ SE MODIFICA O COMPORTAMENTO DO HOMEM AO VOLANTE, QUE SE REVELA PELA ACEITAÇÃO DE RISCOS E DIMINUIÇÃO EM TRANSPOR SINGELAS DIFICULDADES OCORRIDAS NO TRÂNSITO.FALSA PREMISSA DE QUE HÁ ÍNDICES DE CONDIÇÕES

96 CASTRO, Cássio Benvenutti de. Retroatividade secundum eventum probationis do novo art. 306, do CTB. Revista Ibero-Americana de Ciências Penais. Porto Alegre, v. 8, n. 16, jul./dez. 2008, p. 101 97 MARCÃO, Renato. Crimes de Trânsito (anotações e interpretação jurisprudencial da parte criminal da Lei n. 9.503, de 23-9-1997). São Paulo, Saraiva, 2009, p. 159. 
SEGURAS PARA CONDUZIR VEÍCULOS AUTOMOTORES SOB O EFEITO DO ÁLCOOL.ORDEM DENEGADA. UNÂNIME ${ }^{98}$.

APELAÇÃO CRIMINAL. DENÚNCIA NAS PENAS DO ART. 306 DA LEI 9503/97 - DIRIGIR ALCOOLIZADO. ABSOLVIÇÃO SUMÁRIA, NA FORMA DO ART. 397, III DO C. P. PENAL, DIANTE DA AUSÊNCIA DE COMPROVAÇÃO DA DOSAGEM ALCOÓLICA NO SANGUE DO DENUNCIADO. PRETENDE O MINISTÉRIO PÚBLICO A REFORMA DA SENTENÇA, DETERMINANDO-SE O PROSSEGUIMENTO DO FEITO. RESSALTA QUE A CONCENTRAÇÃO DE ÁLCOOL NO SANGUE PODE SER COMPROVADA POR OUTROS MEIOS DE PROVA EM DIREITO ADMITIDOS, DENTRE OS QUAIS O EXAME PERICIAL E OS DEPOIMENTOS REALIZADOS EM JUÍZO. SALIENTA, AINDA, QUE O ART. 306 DA LEI 9503/97 NÃO FOI DERROGADO PELA LEI 11705/08, TENDO, NA REALIDADE, OCORRIDO UMA AMPLIAÇÃO DA NORMA, IMPONDO PENALIDADES MAIS GRAVOSAS. POSSIBILIDADE. NOTE-SE QUE A CONDUTA IMPUTADA AO ACUSADO OCORREU EM DATA ANTERIOR À VIGÊNCIA DA NOVA LEI, TENDO O FATO OCORRIDO EM 26/01/2008. A MAIOR CAUSA DE ACIDENTES DE TRÂNSITO NO BRASIL É A INFELIZ COMBINAÇÃO DE ÁLCOOL E DIREÇÃO, TENDO O LEGISLADOR DECIDIDO PENALIZAR MAIS SEVERAMENTE AQUELES QUE DIRIGEM SOB A INFLUÊNCIA DO ÁLCOOL, IMPOSSIBILITANDO, INCLUSIVE, A APLICAÇÃO DE MEDIDAS DESPENALIZADORAS. O DELITO DE EMBRIAGUEZ AO VOLANTE É CONSIDERADO UM CRIME DE PERIGO ABSTRATO, NÃO SE EXIGINDO A COMPROVAÇÃO EFETIVA DE DANO À INCOLUMIDADE PÚBLICA, OU SEJA, CONDUTA, INDEPENDENTEMENTE DE OUTRO ACONTECIMENTO, DEVE GERAR PERIGO AO BEM JURÍDICO TUTELADO. O TESTE E O EXAME PERICIAL (ETILÔMETRO OU EXAME DE SANGUE) NÃO SÃO OS ÚNICOS MEIOS DE PROVA ADMITIDOS PARA A COMPROVAÇÃO DO ESTADO DE EMBRIAGUEZ, EXISTINDO OUTRAS POSSIBILIDADES DE CONSTATAÇÃO, COMO O EXAME CLÍNICO E A PROVA ORAL PRODUZIDA PELO CRIVO DO CONTRADITÓRIO. NA HIPÓTESE DOS AUTOS, O EXAME DE EMBRIAGUEZ REALIZADO POR PÉRITO-MÉDICO NÃO DEIXA DÚVIDAS QUANTO AO ESTADO DO ACUSADO NO MOMENTO DE SUA PRISÃO EM FLAGRANTE, SENDO O MESMO SUFICIENTE PARA CONSTATAR A EXISTÊNCIA DO ELEMENTO NORMATIVO DO TIPO. RECURSO PROVIDO PARA QUE O PROCESSO PROSSIGA NA FORMA DA LEI ${ }^{99}$.

Os autores Luiz Flávio Gomes, Damásio de Jesus e Silva Sánchez, entretanto, integram a parte da doutrina que propõe uma nova forma de interpretar esse tipo penal, para que não prepondere a interpretação gramatical

98 TJRJ, Habeas Corpus n. 0063279-43.2009.8.19.0000, Rel. Des. Antonio Carlos Amado, Sexta Câmara Criminal, julgamento 26/01/2010.

99 TJRJ, apelação n. 0000602-94.2008.8.19.0037 (2009.050.04719), Rel. Des. Eunice Ferreira Caldas, Sexta Câmara Criminal, julgamento 17/11/2009. 
de que é um crime de perigo abstrato, sob pena de inconstitucionalidade. Trataremos, assim, da interpretação conforme a Constituição por eles proposta.

Luiz Flávio Gomes considera a forma como foram tipificadas as condutas, exigindo-se somente em relação à segunda a elementar "estar sob influência” da substância, um equívoco do legislador, devendo essa elementar ser considerada necessária para a realização de ambas as condutas tipificadas, devendo-se exigir que haja, também, condutor dirigindo sob a influência de álcool. E assim justifica sua posição:

Por quê? Porque do contrário estaríamos admitindo o perigo abstrato no Direito Penal, o que (hoje) é um heresia sem tamanho, principalmente quando se estuda o princípio (constitucional implícito) da ofensividade, incompatível com os delitos de perigo abstrato [...]. Todo tipo legal que descreve um perigo abstrato deve ser interpretado na forma de perigo concreto (ainda que indeterminado, que é o limite mínimo para se admitir um delito, ou seja, a intervenção do Direito Penal) ${ }^{100}$.

Além disso, o autor aponta o fato de que se a infração administrativa que é o "menos" exige que se esteja sob influência de álcool, não pode a infração penal, que é o “mais”, dispensá-la, presumindo o perigo pela simples concentração de álcool no sangue ${ }^{101}$.

Acrescenta, ainda, como argumento, que outros dispositivos, como o artigo $1^{\circ}$ da Lei $11.705 / 2008$ e o artigo 291, parágrafo $1^{\circ}$ mencionam ser crime “dirigir sob a influência de álcool”.

Deste modo, conclui que "estar sob influência" de álcool é uma elementar típica implícita na primeira parte do artigo 306, CTB. E define a referida elementar:

O estar "sob influência" exige a exteriorização de um fato (de um plus) que vai além da embriaguez, mas derivado dela (nexo de causalidade). Ou seja: não basta a

100 GOMES, Luiz Flávio et all.. Comentários às Reformas do Código de Processo Penal e da Lei de Trânsito. São Paulo: Editora Revista dos Tribunais, 2008, p. 376.

101 GOMES, Luiz Flávio et all.. Comentários às Reformas do Código de Processo Penal e da Lei de Trânsito. São Paulo: Editora Revista dos Tribunais, 2008, p. 376. 
embriaguez (o estar alcoolizado, impõe-se a comprovação de que o agente estava sob "sua influência", que se manifesta numa direção anormal (que coloca em risco concreto a segurança viária). Note-se, não se exige a prova do risco concreto para uma pessoa determinada. Não é isso. Basta que a direção tenha sido anormal (em ziguezague, v.g.): isso já é suficiente para se colocar em risco a segurança viária ${ }^{102}$.

No mesmo sentido, Damásio de Jesus afirma que:

É imprescindível que o faça "sob a influência” de álcool etc. Não há, assim, crime quando o motorista, embora provada a presença de mais de seis decigramas de álcool por litro de sangue, dirige normalmente o veículo ${ }^{103}$.

Silva Sanchéz, por sua vez, ao tratar do crime de embriaguez ao volante do ordenamento jurídico espanhol (artigo 340 bis a) $1^{\circ}$., faz diversas críticas ao mesmo, e pode-se dizer que muitas delas também se aplicam ao artigo 306 do Código de Trânsito Brasileiro. Suas críticas são, inclusive, de perspectiva similar às de Luiz Flávio Gomes e Damásio de Jesus.

Em primeiro lugar, o autor afirma que a redação típica não exige nem a lesão, nem o perigo concreto de lesão a bens jurídicos individuais dos intervenientes no trânsito. Entretanto, segundo ele, isso não pode permitir um entendimento do preceito sem qualquer periculosidade real da conduta para bens jurídicos, tendo em vista que o Direito Penal tem como missão a proteção exclusiva a bens jurídicos.

Acentua que, ainda que o crime em referência vise proteger, em última instância, a vida, a saúde e o patrimônio individuais, o fato típico se esgota sem que ocorra qualquer lesão a esses bens jurídicos. Isto, em verdade, revelaria uma intenção do legislador de adiantar a barreira de intervenção penal,

102 GOMES, Luiz Flávio. Embriaguez ao volante: reforma do Código de Trânsito (lei ${ }^{\circ}$ 11.705/2008). Revista Magister de Direito Penal e Processual Penal, Porto Alegre, v. 4, n. 24, , jun./jul. 2008, p. 96.

103 JESUS, Damásio de. Embriaguez ao volante: notas à Lei n ${ }^{\circ}$ 11.705/2008. Revista IOB de Direito Penal e Processual Penal. Porto Alegre. v.9. n.52. out./nov. 2008, p. 35. 
abrangendo fatos que, em tese, não passariam de uma conduta imprudente sem qualquer resultado lesivo ou sem qualquer perigo ${ }^{104}$.

Para promover esse adiantamento, cria-se um bem jurídico supraindividual, “espiritualizado”, que é a segurança do tráfego, já que este é lesionado ao se colocar em perigo abstrato ou genérico, sem qualquer afetação concreta, os bens jurídicos pessoais ou patrimoniais dos indivíduos concretos $^{105}$.

Nesse ponto, vale lembrar o ensinamento do professor Feijóo Sánchez, no sentido de que não se pode perder de vista que, embora se diga que o bem jurídico tutelado é a segurança do trânsito, isso só é possível devido ao fato de estar, em verdade, adiantando as barreiras da proteção penal dos bens jurídicos individuais, esses sim os verdadeiros destinatários da proteção do Direito Penal: (tradução livre)

Em virtude dessas considerações creio que é mais correto entender que a segurança do tráfico é um bem jurídico coletivo intermediário com uma clara referência individual. Desta maneira se pode explicar dogmáticamente que no injusto seja dada relevância a referência a bens jurídicos individuais que são protegidos de forma mediata ou indireta. A segurança como um bem jurídico passa a ser interpretada assim como um meio de proteção de bens jurídicos individuais. E sem essa referência última, creio que se torna muito difícil entender e explicar o fundamento material dos delitos de perigo contemplados no novo Código de Trânsito. Esses delitos se definem materialmente por lesionar a segurança do tráfego como meio de colocar em perigo os bens jurídicos individuais ${ }^{106}$.

104 1. SILVA SANCHEZ, Jesus Maria. Consideraciones sobre el delito del Art. 340 Bis a) $1^{\circ} \mathrm{CP}$ (conduccion bajo la influencia de bebidas alcoholicas, drogas toxicas). Revista Juridica de Catalunya. Baja California Norte, v.92, n.1, p.25-57, 1993, p. 26. Tratando desse mesmo aspecto, Feijóo Sánchez afirma que o Direito Penal vem tentando cumprir sua missão protetiva mudando de estratégia de proteção e se adiantando, antes que o risco se torne incontrolável. Para o autor, esse adiantamento é especialmente necessário quando se trata de âmbitos sociais como o tráfico de veículos e outros em que a ex ante são incontáveis o número de vítimas que pode uma ação perigosa gerar. (FEIJÓO SÁNCHEZ, Bernardo J. Cuestiones básicas de los delitos de peligro abstracto y concreto em relacion com el transito. Revista da Ajuris. Porto Alegre. v.26. n.78. jun. 2000, p. 292).

105 SILVA SANCHEZ, Jesus Maria. Consideraciones sobre el delito del Art. 340 Bis a) $1^{\circ} \mathrm{CP}$ (conduccion bajo la influencia de bebidas alcoholicas, drogas toxicas). Revista Juridica de Catalunya. Baja California Norte, v.92, n.1, 1993, p. 26.

106 FEIJÓO SÁNCHEZ, Bernardo J. Cuestiones básicas de los delitos de peligro abstracto y concreto en relacion con el transito. Revista da Ajuris. Porto Alegre. v.26. n.78., 4. jun. 2000, p. 297. No 
Em seguida, Silva Sánchez acentua que a interpretação gramatical fornece somente o limite externo da interpretação típica. Porém, para saber os comportamentos verdadeiramente punidos pelo tipo penal, deve-se fazer uma interpretação teleológica (orientação do tipo a uma proteção subsidiária, fragmentária e voltada aos bens jurídico-penais) do mesmo, devendo-se distinguir uma mera realização aparente de uma realização efetiva do tipo ${ }^{107}$.

Sua análise se inicia identificando que são quatro os elementos que devem ser conjugados para a formação do referido tipo penal: em primeiro lugar, a introdução no corpo do sujeito ativo, por ingestão, injeção, inalação, fricção, a bebida alcoólica ou as outras substâncias mencionadas; em segundo lugar, que o sujeito conduza um veículo automotor e que essa substância influencie na sua forma de conduzir; em terceiro lugar, que essa influência seja no sentido de afetar a segurança do tráfego, colocando-o em perigo; por fim, que essa afetação da segurança tenha intensidade suficiente, de forma que seja um perigo tipicamente relevante.

Quanto ao primeiro item, é evidente a necessidade de que esteja presente. Entretanto, Silva Sanchéz, nos mesmos moldes das considerações feitas por Luiz Flávio Gomes, considera um erro deter-se nesse elemento, de forma a ter como cometido o delito tão logo se detectasse determinado nível de concentração de álcool no sangue do sujeito. Isso significaria seguir um critério formalista, que converteria o delito de embriaguez ao volante em uma

original: En virtud de estas consideraciones creo que es más correcto entender que la seguridade del tráfico es un bién jurídico colectivo intermédio com un claro referente individual. De esta manera se puede explicar dogmáticamente que en el injusto cobre relevancia la referencia a bienes jurídicos individuales que son protegidos de forma mediata o indirecta. La seguridad como bien jurídico pasa a interpretarse así como un medio de protección de bienes jurídicos individuales. Y sin esse referente último creo que resulta muy difícil entender y describir el fundamento material de los delitos de peligro contemplados en el nuevo Código de tránsito. Estos delitos se definen materialmente por lesionar la seguridad del tráfico como medio de puesta em peligro de bienes jurídicos individuales.

107 1. SILVA SÁNCHEZ, Jesús-Maria. Consideraciones sobre el delito del Art. 340 Bis a) $1^{\circ}$ CP (conduccion bajo la influencia de bebidas alcoholicas, drogas toxicas). Revista Jurídica de Catalunya. Baja California Norte, v.92, n.1, 1993, p. 27. 
norma penal em branco, que se consumaria pela mera infração da norma administrativa sobre segurança viária. Para ele, uma interpretação tão formalista como essa não é admissível.

Além disso, ele aponta que haveria uma grande desigualdade no tratamento no caso do álcool e no caso das demais substâncias. É que estas não têm sequer um parâmetro fora do direito penal que nos informe o máximo de concentração no sangue que poderia ser admitido. Assim, enquanto no caso do álcool a perspectiva seria formalista-geral, neste último caso haveria de ser individual-material.

Nesse sentido, seria imperioso reconhecer que não basta um dado nível de álcool no sangue do indivíduo para que o tipo se realize. É necessário, também, que essa quantidade de álcool tenha realmente influenciado na forma de condução do veículo. Esse entendimento constituiria um avanço em relação ao critério formalista, impondo a adoção de um critério individual-material, segundo o qual deverá ser avaliado se determinada quantidade de álcool no sangue influenciou realmente a forma de conduzir de um sujeito de um dado caso concreto em exame. Seria necessário, igualmente, que tal substância tivesse uma influência negativa na condução, gerando uma diminuição na concentração, nos reflexos, ou numa ausência de sentido crítico ou de responsabilidade no condutor ${ }^{108}$.

Como demonstrado acima, Luiz Flávio Gomes e Damásio de Jesus compartilham desse entendimento, tanto que trataram como inadmissível que o

\footnotetext{
108 No mesmo sentido, Luiz Flávio Gomes, ao tratar da interpretação literal do dispositivo que vem sendo feita: "Essa interpretação, contudo, como já alertamos, parece incompatível com a nova ordem constitucional, sobretudo quando se considera que estaríamos diante de uma presunção iuris et de iure, isto é, de uma afirmação categórica generalista, que iria ter incidência automática em todos os casos (ainda que o motorista estivesse dirigindo corretamente). Note-se que a presunção de perigo abstrato não admite prova em contrário. Seria uma presunção absoluta, típica dos regimes autoritários ou totalitários”. (GOMES, Luiz Flávio et all.. Comentários às Reformas do Código de Processo Penal e da Lei de Trânsito. São Paulo: Editora Revista dos Tribunais, 2008, p. 377).
} 
tipo penal não exigisse que a condução se desse sob influência de álcool. Enumeraram, por isso, uma série de argumentos que levaram a inevitável conclusão de que esse elemento típico está implícito na primeira parte do artigo 306, CTB.

Além de Luiz Flávio Gomes e Silva Sánchez, o autor Morillas Fernández também destaca a necessidade de o condutor estar sob influência da bebida alcoólica, dirigindo de forma anormal, não bastando a simples prova advinda dos exames de alcoolemia: "Este último critério conduz implícito consigo que a prova da alcoolemia não é requisito exclusivo para apreciar o tipo penal”109 (tradução livre)

O autor prossegue com a seguinte explicação, tratando das diferenças entre o ilícito administrativo e o penal: (tradução livre)

O primeiro constitui uma infração meramente formal, no sentido de que basta realizar a prova do etilômetro para, no caso de superar os limites legalmente estabelecidos, impor a correspondente infração administrativa; frente ao segundo, em que não se aprecia essa característica formal, mas sim uma constatação objetiva, já que a pena não será imposta com a mera prova da alcoolemia, sendo necessário verificar que a referida ingestão afetou a capacidade psicofísica do condutor e, como conseqüência, a segurança do trânsito, que é o bem jurídico protegido pela presente tipologia delituosa ${ }^{110}$.

Quanto ao terceiro item, qual seja, a real periculosidade da conduta, que a influência realmente coloque o tráfego em perigo, Silva Sánchez ressaltou a importância do acolhimento deste elemento. Com ele, fica claro que a

109 MORILLAS FERNÁNDEZ, David Lorenzo. La conducción de vehículos a motor bajo la influencia del alcohol. Cuadernos de Política Criminal, Madrid, n. 87, 2005, p. 82/83. No original:

"Este último criterio lleva implícito consigo que la prueba de alcoholemia no sea requisito exclusivo para apreciar el tipo penal”.

110 MORILLAS FERNÁNDEZ, David Lorenzo. La conducción de vehículos a motor bajo la influencia del alcohol. Cuadernos de Política Criminal, Madrid, n. 87, 2005, p. 89/90. No original: “el primero constituye una infracción meramente formal en el sentido de que basta practicar la prueba del etilómetro para, en el caso de superar los límites legalmente establecidos, imporner la correspondiente sanción administrativa; frente al segundo, donde no se aprecia esa calidad formal sino una constatación objetiva, ya que la pena no será impuesta con la mera prueba de alcoholemia sino que es necesario acreditar que dicha ingestión ha afectado a la capacidad psicofísica del conductor y, en consecuencia, a la seguridade del tráfico, que es el bien jurídico protegido en la presente tipologia delictual. 
concentração de álcool no sangue não pode ser o único dado determinante, já que uma mesma quantidade de álcool ingerida pode ter diferentes efeitos dependendo do indivíduo ${ }^{111}$. Além disso, devem-se considerar as circunstâncias em que o álcool foi ingerido, como sua ingestão juntamente com comida, ou combinação com medicamentos, e, igualmente, as condições em que se dirige, se se trata de via perigosa, as condições meteorológicas (escuridão, chuva, neblina), etc.

Assim, fazendo-se a devida ponderação dos fatores acima, Silva Sánchez conclui que haverá casos em que a ingestão de álcool foi grande, mas a periculosidade não foi expressiva e, por outro lado, haverá casos de pequena ingestão de álcool, mas, dadas as demais condições, a periculosidade da condução do veículo foi alta.

Portanto, da mesma forma que Luiz Flávio Gomes demonstrou com sua lição, os ensinamentos de Silva Sánchez nos conduzem à compreensão de que o que deve configurar como autêntico contorno do tipo penal não é a concentração de álcool no sangue, mas a ofensividade da conduta do indivíduo, dadas todas as circunstâncias do caso concreto. Afinal, pelo princípio da fragmentariedade, não deve ser suficiente qualquer imprudência para se configurar o ilícito penal, devendo ser uma infração grave do dever de cuidado $^{112}$.

Miguel Reale Júnior chega à idêntica conclusão:

Do exposto podemos concluir que, se a ciência médica possui elementos para

111 Luiz Flávio Gomes faz esta mesma ressalva: “Aliás, é conhecido o estudo de que a influência do álcool nas pessoas varia conforme a altura e o peso do indivíduo, o sexo, etc. [...] Nem sempre o dirigir com concentração de álcool por litro de sangue igual ou superior a 6 (seis) decigramas significa conduzir anormalmente. (GOMES, Luiz Flávio et all.. Comentários às Reformas do Código de Processo Penal e da Lei de Trânsito. São Paulo: Editora Revista dos Tribunais, 2008, p. 377).

112 SILVA SÁNCHEZ, Jesús-Maria. Consideraciones sobre el delito del Art. 340 Bis a) $1^{\circ} \mathrm{CP}$ (conduccion bajo la influencia de bebidas alcoholicas, drogas toxicas). Revista Juridica de Catalunya. Baja California Norte, v.92, n.1, 1993, p.36. 
determinar a dosagem alcoólica e os sintomas próprios de cada grau de embriaguez, ocorre, entretanto, que por não suceder correlação exata entre a dosagem alcoólica e os sintomas, como também pela interferência de fatores individuais que modificam esta sintomatologia, não se pode se ater exclusivamente, para determinação da embriaguez, a critérios objetivos de dosagem alcoólica.

Cabe, portanto, o exame de cada caso concreto, porque não ocorre uma relação exata e obrigatória entre a quantidade de álcool no sangue e as repercussões no sistema nervoso ${ }^{113}$.

\section{O entendimento acima explanado é também adotado em alguns}

julgados, como, por exemplo, no que se encontra abaixo transcrito:

Habeas corpus objetivando o trancamento de ação penal, sob alegação de inépcia da denúncia, por não descrever a condução anormal, sob a influência de álcool, por parte da paciente na direção de veículo automotor, bem como a decretação da nulidade da prisão em flagrante pelos mesmos fundamentos e do termo de fiança, com ressarcimento dos valores indevidamente pagos.O libelo inicial relata que a paciente conduzia veículo automotor em via pública, e, ao realizar o teste do etilômetro, o aparelho acusou o resultado de 0,60 mg de álcool por litro de ar expelido dos pulmões, ou seja, com concentração de álcool acima do limite legal.O artigo 306 Código de Trânsito Brasileiro (Lei $\mathrm{n}^{0}$ 9.503/97) tipifica a seguinte conduta: "Conduzir veículo automotor, na via pública, estando com concentração de álcool por litro de sangue igual ou superior a 6 (seis) decigramas, ou sob a influência de qualquer outra substância psicoativa que determine dependência".Embora este texto não faça expressa referência ao "estar sob a influência de álcool" para caracterizar o crime, tal situação se faz imprescindível, pois, caso contrário, a infração administrativa prevista no artigo 165 do mesmo estatuto legal ("Dirigir sob a influência de álcool ou de qualquer outra substância psicoativa que determine dependência") seria mais grave do que a infração penal.Conforme destacou o Des. Gilmar Augusto Teixeira, no voto proferido no habeas corpus $n^{0}$ 2009.059.08115, "Constitui um absurdo considerar que a infração administrativa, que é menos, faz tal exigência, enquanto no delito, que é o mais, bastaria o simples perigo abstrato".Força chamar a atenção para a segunda parte do próprio artigo 306, que reza que constitui crime conduzir veículo "sob a influência de qualquer outra substância psicoativa que determine dependência".Acrescente-se, ainda, que o artigo $1^{\circ}$ da Lei $n^{\circ} 11.705 / 08$, chamada Lei Seca, dispõe que "Esta Lei altera dispositivos da Lei $n^{\circ} 9.503$, de 23 de setembro de 1997, que institui o Código de Trânsito Brasileiro, com a finalidade de estabelecer alcoolemia 0 (zero) e de impor penalidades mais severas para o condutor que dirigir sob a influência de álcool .", e obriga os estabelecimentos comerciais em que se vendem ou oferecem bebidas alcoólicas a estampar, no recinto, aviso de que constitui crime dirigir sob a influência de álcool.Outrossim, ao acrescentar o $\S 1^{\circ}$ ao artigo 291 do Código de Trânsito, a Lei $n^{0} 11.705$ excluiu a aplicação da Lei $n^{\circ}$ 9.099/95 no crime de lesão corporal culposa no trânsito, na hipótese de estar o agente dirigindo "sob influência de álcool ou qualquer outra substância psicoativa que determine dependência".Em conclusão, faz-se necessária a descrição na denúncia de

113 REALE JÚNIOR, Miguel. Crime de embriaguez ao volante. Revista de Direito Penal. Rio de Janeiro, n. 6, abr./jun. 1972, p. 82. 
que o agente estava conduzindo o veículo automotor sob influência de álcool, indicando o fato exterior, ou seja, a conduta anormal, a qual já é suficiente para expor a risco a segurança viária, e não apenas afirmar que foi ultrapassado o limite legal de concentração de álcool no sangue, que constitui tão somente infração administrativa.No que tange ao ressarcimento da fiança, o artigo 337 do Código de Processo Penal reza que "se a fiança for declarada sem efeito ou passar em julgado a sentença que houver absolvido o réu ou declarado extinta a ação penal, o valor que a constituir será restituído sem desconto .", e, assim, no momento próprio poderá ser requerido ao juízo a quo o levantamento da fiança.Ordem parcialmente concedida, tão somente para declarar a inépcia da denúncia, e, assim, trancar a ação penal ${ }^{114}$.

Com tudo isso visto acima, podemos dizer, sem qualquer dúvida, que o crime de embriaguez ao volante é uma expressão clara do fenômeno da “administrativização” do Direito Penal. Há de certa forma, nesse tipo penal, reflexo das características do Direito Penal administrativizado, que expusemos em capítulo próprio.

Em primeiro lugar, o bem jurídico tutelado é a segurança viária, bem esse de natureza supraindividual, sendo os bens individuais, como saúde e integridade física, mera ratio legis. Acaba-se por tutelar um modelo de gestão de riscos setoriais, tutelando-se certos comportamentos padronizados, e punindo-se aqueles que não se conformam com os riscos admitidos. Tal forma de racionalizar é própria do Direito Administrativo sancionador.

Além disso, o fato de ser uma norma penal em branco, tendo o parágrafo único do artigo 306 estabelecido que o Poder Executivo federal estipulará a equivalência entre distintos testes de alcoolemia, faz com que, em situações de apuração do nível de concentração de álcool no sangue somente pelo etilômetro, o crime se constitua pela mera desobediência a norma de caráter administrativo ${ }^{115}$.

114 TJRJ, Habeas Corpus n. 0010274-72.2010.8.19.0000, Relator: Des. Marcus Quaresma, Órgão julgador: Oitava Câmara Criminal, Julgamento, 24/03/2010.

115 PELUSO, Vinicius de Toledo Piza. O crime de embriaguez ao volante e o "bafômetro": algumas observações. Boletim IBCCRIM. São Paulo, v. 16, n. 189, ago/2008, p. 16. 
Em segundo lugar, a tipificação da conduta como delito de perigo abstrato é uma violação ao princípio da ofensividade. A referida técnica legislativa acaba por dar, ao ilícito penal, contornos do ilícito administrativo, pois a presunção de lesividade quando se verifica uma certa concentração de álcool no sangue é fruto de uma avaliação estatística, geral e não casuística. Pode-se dizer, com isso, que a adoção da técnica de criminalizar utilizando-se de crimes de perigo abstrato é uma das expressões do fenômeno da “administrativização” do Direito Penal, passando para este ramo do direito a punição de condutas próprias do Direito administrativo sancionador.

O mesmo se diga em relação ao fato de essa concentração de álcool nem sempre ser correspondente ao grau de perigo gerado para a segurança viária. Isto é, a pena não é imposta pela gravidade da conduta do sujeito, o que se dá em manifesta violação ao princípio da culpabilidade e proporcionalidade.

Por fim, a criminalização da embriaguez ao volante, como se deu, não deveria integrar o ramo do direito tido como a ultima ratio, podendo tal forma de punir o sujeito ser perfeitamente desempenhada pelo Direito Administrativo sancionador.

Assim é o que explica Feijóo Sanchez, ao tratar dos crimes de trânsito como crimes de perigo abstrato: (tradução livre)

\begin{abstract}
Por isso se considera que certos âmbitos sociais, como o tráfego viário, devem ser organizados mediante uma uniformização máxima das condutas (mediante condutas padrão). As infrações mais relevantes contra essa uniformização ou esse modelo necessário de gestão uniformizada abandonam o direito administrativo sancionador para passar a fazer parte da ultima ratio do ordenamento jurídico. Aqui surge o problema político-criminal da distinção entre injusto administrativo e injusto especificamente penal e o fundamento quantitativo ou qualitativo da referida diferenciação ${ }^{116}$.
\end{abstract}

116 FEIJÓO SÁNCHEZ, Bernardo J. Cuestiones basicas de los delitos de peligro abstracto y concreto en relacion con el transito. Revista da AJURIS. Porto Alegre, v.26, n.78, jun. 2000, p. 302/303. No original: "Por ello, se considera que ciertos âmbitos sociales como el tráfico viário deben ser 
Aliás, ao analisar especificamente o Código de Trânsito Brasileiro, ainda que em período anterior às últimas modificações legislativas, Feijóo Sánchez foi preciso no sentido de ratificar o que aqui tentamos expor, ao dizer que as normas do Código de Trânsito Brasileiro são, de certa forma, mero reforço do comportamento que se visa obter com as normas administrativas. E, ainda que tenha havido a referida alteração no artigo 306, CTB, a lição, em vez de ultrapassada, tornou-se ainda mais atual: (tradução livre)

A primeira questão que chama a atenção com relação aos novos crimes de trânsito é que esses operam claramente como reforço das normas administrativas sancionadoras estabelecidas no Código de Trânsito, isto é, como normas que tentam reforçar a gestão do tráfico viário. ${ }^{117}$.

\title{
3.2. O crime da embriaguez no volante e o direito ao silêncio
}

O Código de Trânsito Brasileiro trata dos meios probatórios que podem conduzir à constatação da infração de embriaguez ao volante (administrativa ou penal) em seu artigo 277:

\begin{abstract}
Art. 277. Todo condutor de veículo automotor, envolvido em acidente de trânsito ou que for alvo de fiscalização de trânsito, sob suspeita de dirigir sob a influência de álcool será submetido a testes de alcoolemia, exames clínicos, perícia ou outro exame que, por meios técnicos ou científicos, em aparelhos homologados pelo CONTRAN, permitam certificar seu estado.

$\S 1^{0}$ Medida correspondente aplica-se no caso de suspeita de uso de substância entorpecente, tóxica ou de efeitos análogos.
\end{abstract}

organizados mediante uma estandarización máxima de las condutas (mediante conductas patrón). Lãs infracciones más relevantes contra esa estandarización o esse modelo necesario de gestión estandarizada abandonan el derecho administrativo sancionador para pasar a formar parte de la ultima ratio del ordenamiento jurídico. Aquí surge el problema político-criminal de la distinción entre injusto administrativo e injusto específicamente penal y el fundamento cuantitativo o cualitativo de dicha diferenciación”.

117 FEIJÓO SÁNCHEZ, Bernardo J. Cuestiones básicas de los delitos de peligro abstracto y concreto em relacion com el transito. Revista da Ajuris. Porto Alegre. v.26. n.78., 4. jun. 2000, p. 294. No original: "La primeira cuestión que llama la atención com respecto a los nuevos crimes de transito es que éstos operan claramento como refuerzo de las normas administrativas sancionadoras recogidas em el Código de tránsito, es decir, como normas que intentan reforzar la gestión del tráfico viário.”. 
$\S 2^{0}$ A infração prevista no art. 165 deste Código poderá ser caracterizada pelo agente de trânsito mediante a obtenção de outras provas em direito admitidas, acerca dos notórios sinais de embriaguez, excitação ou torpor apresentados pelo condutor.

$\S 3^{0}$ Serão aplicadas as penalidades e medidas administrativas estabelecidas no art.

165 deste Código ao condutor que se recusar a se submeter a qualquer dos procedimentos previstos no caput deste artigo.

Pode-se dizer que as três formas principais de se provar a embriaguez ao volante são: o exame de sangue, o etilômetro (“bafômetro”), e o exame clínico. São admitidos também, conforme o dispositivo legal acima mencionado, quaisquer outras provas em direito admitidas, como, por exemplo, prova testemunhal, fotos, filmagens, etc ${ }^{118}$.

Luiz Flávio Gomes, ao tratar do tema das provas admitidas pelo CTB, alerta para o direito do cidadão de não fazer prova contra si mesmo. Essa seria, para o autor, uma premissa básica a ser observada, tendo em vista sua previsão expressa no já mencionado artigo $8^{\circ}$ da Convenção Americana sobre Direitos Humanos, a que atribui valor constitucional. Assim, não se pode obrigar o sujeito a ceder seu corpo ou, ainda, parte dele para contribuir com a colheita de provas, principalmente se isso se der contra ele. Em seguida, esclarece:

Em outras palavras: não está obrigado a ceder sangue, não está obrigado a soprar o bafômetro (porque essas duas provas envolvem o corpo humano do suspeito e porque exigem dele uma postura ativa). Havendo recusa, resta o exame clínico (que é feito geralmente nos Institutos Médico-Legais) ou a prova testemunhal ${ }^{119}$.

Dessa forma, entende-se que o condutor surpreendido pode, em razão de seu direito ao silêncio, recusar-se a fazer o exame de sangue e o bafômetro, mas não pode recusar-se ao exame clínico. Se houver recusa, aplicam-se as penalidades da infração administrativa, conforme determina o artigo 277, parágrafo $3^{\circ}$ acima transcrito.

118 GOMES, Luiz Flávio. Bafômetro: é obrigatório?. Revista Magister de Direito Penal e Processual Penal. Porto Alegre, v. 6, n. 31, ago./set. 2009, p. 12.

119 GOMES, Luiz Flávio. Bafômetro: é obrigatório?. Revista Magister de Direito Penal e Processual Penal. Porto Alegre, v. 6, n. 31, ago./set. 2009, p. 13. 
O autor Renato Marcão, em seus comentários ao Código de Trânsito, compartilha do entendimento de que, em respeito ao princípio da vedação à auto-incriminação, o condutor surpreendido não pode ser sancionado por recusar-se a realizar o exame de sangue e "bafômetro":

Nada obstante a letra expressa da lei, que é taxativa ao impor que nas situações catalogadas no caput do art. 277 o condutor será submetido aos procedimentos que menciona, e que a recusa configura infração administrativa $\left(\S 3^{\circ}\right)$, na verdade o condutor não está obrigado, e a autoridade nada poderá contra ele fazer no sentido de submetê-lo, contra sua vontade, a determinados procedimentos visando apurar concentração de álcool por litro de sangue. Não poderá, em síntese, constrangê-lo a exames de alcoolemia (sangue, v.g. ou teste em aparelho de ar alveolar pulmonar (etilômetro), vulgamente conhecido por “bafômetro”.

Pelas mesmas razões que veremos abaixo, também a infração administrativa prevista no $\S 3^{\circ}$ do art. 277 do Código de Trânsito brasileiro, não subsiste.

O autor prossegue, sendo ainda mais abrangente:

É o que basta para afirmarmos que o agente surpreendido na via pública [...] não poderá ser submetido, contra sua vontade, sem sua explicita autorização, a qualquer procedimento que implique intervenção corporal, da mesma maneira que não está obrigado a se pronunciar a respeito de fatos contra si imputados (art. 50, LXIII), sem que de tal "silêncio constitucional" se possa extrair qualquer conclusão em seu desfavor $^{120}$.

\section{Callegari:}

Sobre o assunto, nesse sentido também se manifestou André Luís

Diante desses argumentos, indaga-se se a negativa do agente em realizar a prova de alcoolemia no momento em que é detido poderia resultar em sua incriminação. É que parece sustentável que qualquer gênero de coação suporia uma violação expressa ao direito fundamental a defesa e, inclusive, em alguns casos, poderia tipificar um delito de coação praticado pela própria autoridade. Saliente-se que a obrigatoriedade ao exame tanto do sopro de ar como a retirada de sangue, ferem o direito de liberdade do sujeito e, realizados mediante força ou ameaça, podem tipificar delitos próprios. Ainda que o novo Código mencione que o sujeito será submetido aos referidos testes, estes não podem ser obrigatórios, a não ser a realização de um exame clínico no momento da detenção ${ }^{121}$.

120 MARCÃO, Renato. Crimes de Trânsito (anotações e interpretação jurisprudencial da parte criminal da Lei n. 9.503, de 23-9-1997). São Paulo: Saraiva, 2009, p. 162.

121 CALLEGARI, André Luís. A inconstitucionalidade do teste de alcoolemia no código de trânsito brasileiro. In: CALLEGARI, André Luís. Imputação objetiva: lavagem de dinheiro e outros temas de direito penal. Porto Alegre: Livraria do Advogado, 2001, p. 179. 
Como visto no capítulo referente à garantia da vedação a autoincriminação, isso se dá porque ao Estado cabe realizar a prova da culpabilidade, sendo a regra a busca de provas que independam da colaboração do acusado:

O sentido do direito a não declarar como manifestação do direito à defesa se assenta na obrigação para o Estado de suportar a carga da prova da culpabilidade daquele que se presume inocente. Este tem direito a não colaborar no descobrimento de sua culpabilidade, como compensação da maior debilidade de sua posição. Por isso se fala de um genérico direito a não colaborar, e nesta linha deve os ter presente que os meios de que dispõe o Estado para a investigação dos delitos se aperfeiçoam - e podem seguir se aperfeiçoando - incluindo muitas possibilidade que a simples declaração verbal do imputado ${ }^{122}$.

Damásio de Jesus, em estudo sobre o tema, reforça o posicionamento de que ninguém é obrigado a fazer exame de sangue ou se submeter ao teste do bafômetro, em razão do princípio Nemo tenetur se detegere, constitucionalmente consagrado.

Nessa linha, o autor acredita que, por tratar-se de um direito de status constitucional, não pode seu exercício, ou seja, a recusa aos exames de alcoolemia, ter qualquer conseqüência para o acusado, não respondendo o mesmo por crime de desobediência. Igualmente, não pode nenhuma regra infraconstitucional, principalmente de caráter administrativo, servir de instrumento de persuasão para que o imputado viole seus direitos fundamentais. Isso porque, embora se diga que o direito ao silêncio é direito do preso, Damásio de Jesus entende, como a doutrina dominante, ser ele aplicável a qualquer pessoa, detida ou não. Ele ainda conclui que:

122 CALLEGARI, André Luís. A inconstitucionalidade do teste de alcoolemia no código de trânsito brasileiro. In: CALLEGARI, André Luís. Imputação objetiva: lavagem de dinheiro e outros temas de direito penal. Porto Alegre: Livraria do Advogado, 2001, p. 181. 
Nessa linha de raciocínio, é necessário concluir que técnicas científicas encontram obstáculo intransponível em nosso ordenamento, em função do direito à não autoincriminacao e especialmente do principio da presunção de inocência ${ }^{123}$.

Por outro lado, há autores que acreditam que o direito de permanecer calado não autorizaria que o motorista surpreendido pudesse se recusar a fazer o exame de alcoolemia. Em artigo em que defende a validade do exame de alcoolemia como prova no processo penal, Isaac Sabbá invoca o princípio da proporcionalidade para defender seu ponto de vista:

Pense-se na recusa do motorista de submeter-se ao exame de alcoolemia, invocando a prerrogativa de não se incriminar. [...]

A norma que prescreve a necessidade do exame de alcoolemia, enfeixando nela própria a identificação de alguma conduta criminosa, acaba por representar teleologicamente o legítimo interesse de preservação dos bens jurídicos da vida e da integridade física. [...]

Muito embora não prescrito expressamente no texto constitucional, temos de admitir que a harmonização dos direitos fundamentais passa pela aceitação do princípio da proporcionalidade. [...] Por esta via, o direito a permanecer calado não alcançaria a negativa ao exame de alcoolemia, expressando-se, pois, de forma menos abrangente ${ }^{124}$.

Vê-se, assim, que há quem defenda a impossibilidade da recusa pelo condutor de realizar os testes de alcoolemia. Havendo, assim, quem defenda a interpretação de forma literal do artigo 277, § $3^{\circ}$, CTB ("Serão aplicadas as penalidades e medidas administrativas estabelecidas no art. 165 deste Código ao condutor que se recusar a se submeter a qualquer dos procedimentos previstos no caput deste artigo"), aplicando a referida sanção até mesmo a recusa ao exame de sangue e "bafômetro". Entretanto, a interpretação estritamente gramatical do referido dispositivo leva-nos a uma solução inconstitucional. E isso porque:

123 JESUS, Damásio Evangelista de. Limites à prova da embriaguez ao volante: a questão da obrigatoriedade do teste do bafômetro. Revista Síntese de Direito Penal e Processual Penal. Porto Alegre, v.5, n.28, out./nov. 2004, p. 29. Tal posição é manifestada também no artigo "Notas à lei 11.705/2008”, p. 37: “Ora, se a recusa tem fundamento constitucional, tratando-se de atitude lícita, como aplicar pena ao conductor?”.

124 GUIMARÃES, Isaac Sabbá. Exame de alcoolemia: sua validade como prova no processo penal. Revista Brasileira de Ciências Criminais, São Paulo, n. 33, jan./mar. 2001, p. 131/132. 
Note-se que todo suspeito tem direito de não produzir prova contra si mesmo. Logo, não está obrigado a fazer exame de sangue ou soprar bafômetro. Nessas duas situações, por se tratar de um direito, não há que se falar em qualquer tipo de sanção (penal ou administrativa). Ninguém pode ser punido por exercer um direito. [...] O que está autorizado por uma norma não pode estar proibido por outra ${ }^{125}$.

Considerando o que foi acima exposto, fica claro que, em decorrência das mudanças ocorridas com a Lei 11.705/08, só poderá ser alvo da persecução penal aquele que se submete, voluntariamente ao "bafômetro" ou exame de sangue. Ou, ainda, aquele que não for devidamente informada do seu direito.

É por isso, aliás, como bem ressaltado no capítulo destinado ao princípio nemo tenetur se detegere, que há a obrigação por parte da autoridade de informar ao suspeito ou acusado de que possui o direito de não se autoincriminar. No caso, significa não se submeter ao exame de sangue e ao teste do etilômetro, sem que daí decorra qualquer conseqüência negativa, tendo em vista que se trata de exercício de direito constitucional ${ }^{126}$.

Dessa forma, considerando-se a ampla aplicação do princípio nemo tenetur se detegere, conclui-se que as decorrências extraídas deste princípio, conforme exposto em capítulo próprio, devem se aplicar aos exames de etilômetro e exame de sangue. Ou seja, o indivíduo não pode ser coagido a realizar os referidos exames; deve ser devidamente informado de seu direito de não se auto-incriminar; deve haver requisitos rígidos, em caso de realização do teste, para apurar se realmente houve o consentimento do motorista surpreendido; e a recusa à realização do exame não pode ensejar o cometimento do crime de desobediência ou a aplicação de penalidades administrativas.

125 GOMES, Luiz Flávio. Bafômetro: é obrigatório?. Revista Magister de Direito Penal e Processual Penal. Porto Alegre, v. 6, n. 31, ago./set. 2009, p. 13

126 MARCÃO, Renato. Crimes de Trânsito (anotações e interpretação jurisprudencial da parte criminal da Lei n. 9.503, de 23-9-1997). São Paulo: Saraiva, 2009, p. 165. 


\subsection{Interpretações que vêm sendo dadas à lei.}

Nos itens anteriores, ficou claro que o crime de embriaguez ao volante, especialmente por ter sido construído sob a forma de um delito de perigo abstrato, é uma projeção, num tipo determinado, de uma tendência de transformação que o Direito Penal vem sofrendo, denominada “administrativização".

Além disso, explicitou-se também que a forma de construção do tipo penal, estabelecendo uma taxa de concentração de álcool no sangue para que o crime se configure, foi feita sem a devida consideração do princípio Nemo tenetur se detegere, já que os exames técnicos explicitados dependem de colaboração do imputado.

Em vista disso, faremos uma relação de algumas das interpretações que vem sendo adotadas, diante dos dilemas que se colocaram com a mudança promovida pela Lei 11.705/2008, bem como as principais críticas que se pode fazer a elas.

Uma primeira interpretação que se tem visto é a interpretação literal da primeira parte do artigo 306, CTB, isto é, de forma que constitua crime de perigo abstrato ${ }^{127}$. De acordo com essa interpretação, o tipo penal se realizaria com a condução de veículo automotor, na via pública, estando com concentração de álcool igual ou superior a 6 (seis) decigramas por litro de sangue $^{128}$.

127 No sentido de que basta a concentração de álcool por litro de ar expelido, ainda que a denúncia não descreva estar o agente "sob influência de álcool": STJ, Habeas Corpus 155069, Relatora: Min. Laurita Vaz, Órgão Julgador: Quinta Turma, Publicação: Dje 26/04/2010 e TJRJ, Habeas Corpus n. 0061086-55.2009.0000, Relatora: Des. Rosita Oliveira Netto, Órgão Julgador: Sexta Câmara Criminal, Publicação: 16/04/2010.

128 Segundo Renato Marcão, “o dispositivo penal é taxativo no que tange à quantificação de álcool por litro de sangue para que se tenha por configurada a infração penal, e tal apuração só poderá ser 
A principal crítica que se pode fazer é que nem sempre conduzir com essa concentração de álcool no sangue leva o condutor a dirigir anormalmente. Seria um crime de perigo abstrato, por tratar-se de presunção absoluta. Tal forma de criminalização não é compatível com nossa ordem constitucional atual. Além disso, os únicos meios que podem apurar a taxa de álcool no sangue dependem da colaboração do acusado, de forma que, ou se viola seu direito ao silêncio, aplicando sanções a sua eventual recusa, ou a persecução penal fica condicionada à aceitação do acusado em se submeter aos testes.

Há uma segunda interpretação segundo a qual tanto o dispositivo 165, como o artigo 306, exige o "estar sob influência”. Assim, o delito do artigo 306 não seria de perigo abstrato. Exigiria, além da condição do motorista (estar alcoolizado ou sob efeito de substância psicoativa), também uma direção anormal, denominando-se perigo concreto indeterminado (nesse caso, há uma diminuição da segurança viária sem, necessariamente, haver uma vítima concreta) $^{129}$.

Esse entendimento, exposto por Luiz Flávio Gomes, nos conduz a algumas conclusões: (a) Ocorre a infração administrativa se o condutor tiver qualquer concentração de álcool no sangue (art. 276 c/c 165, CTB), desde que além das margens de tolerância do artigo 276, parágrafo único, CTB (abaixo delas, não configura infração administrativa ou penal ${ }^{130}$ ); (b) Até 6 (seis)

feita tecnicamente, de maneira que a prova respectiva não poderá ser suprida por outros meios, tais como exame clínico e prova oral”. (MARCÃO, Renato. Crimes de Trânsito (anotações e interpretação jurisprudencial da parte criminal da Lei n. 9.503, de 23-9-1997). São Paulo: Saraiva, 2009, p. 160).

129 GOMES, Luiz Flávio et all.. Comentários às Reformas do Código de Processo Penal e da Lei de Trânsito. São Paulo: Editora Revista dos Tribunais, 2008, p. 378/379. Entre outros julgados, o seguinte consagra esse entendimento: TJRJ, Recurso em sentido estrito n. 0199642-34.2009.8.19.0001 (2009.051.00728), Relatora: Des. M.SANDRA KAYAT DIREITO, Órgão Julgador: Quarta Câmara Criminal, Julgamento: 12/01/2010.

130 Referindo-se aos equívocos cometidos em operações policiais, Luiz Flávio Gomes menciona: “1) Quantidade ínfima de álcool no sangue deve ser desconsiderada. Uma pessoa chegou a ser flagrada depois de ter ingerido dois bombons com licor. Isso é um exagero. Por mais que se queira evitar tantas mortes no trânsito brasileiro (mais de 35 mil por ano), não pode nunca a Administração Pública atuar com falta de razoabilidade. Quem usa um anti-séptico bucal não pode sofrer nenhum tipo de sanção. A 
decigramas, somente haverá a infração administrativa; (c) A partir de 6 (seis) decigramas, infração penal (se houver direção anormal) ou infração administrativa (se o condutor dirigir normalmente) ${ }^{131}$; (d) a prova pode ser feita por exame de sangue, etilômetro ("bafômetro") e exame clínico. (e) Aos dois primeiros, o motorista pode se recusar a se submeter (em razão da garantia contra a auto-incriminação, constitucionalmente assegurada), mas ao terceiro não. Recusando-se, a solução não seria prisão por desobediência, mas aplicação de penalidade da infração administrativa (art. 277, parágrafo $3^{\circ}$, (TB) ${ }^{132}$.

Uma crítica a essa interpretação é que havendo a recusa do motorista em realizar o exame de sangue ou o "bafômetro", restam somente o exame clínico e o testemunhal e esses, embora possam comprovar uma eventual direção anormal, não podem comprovar a concentração de álcool no sangue. Assim, toda vez que o condutor fizer uso de seu direito ao silêncio, deverá ser necessariamente absolvido, por ausência absoluta de prova da elementar do tipo $^{133}$.

infração administrativa do artigo 165 exige estar sob a influência do álcool ou outra substância psicoativa. (GOMES, Luiz Flávio. Lei Seca (Lei n. 11.705/2008): exageros, equívocos e abusos das operações policiais. Revista IOB de Direito Penal e Processual Penal. Porto Alegre, v. 9, n. 51, ago./set. 2008, p. 208) .

131 Referindo-se aos equívocos cometidos em operações policiais, Luiz Flávio Gomes menciona: “2) Um grave equivoco que deve ser evitado consiste em prender em flagrante o sujeito todas as vezes que estiver dirigindo com seis decigramas ou mais de álcool por litro de sangue (0,3 no bafômetro - que equivale a dois copos de cerveja). A existência do crime do art. 306 pressupõe não só o estar bêbado (sob a influência do álcool ou outra substância psicoativa), senão também o dirigir anormalmente (em ziguezague, v.g.). Ou seja: condutor anormal (bêbado) + condução anormal (que coloca em risco concreto a segurança viária). (GOMES, Luiz Flávio. Lei Seca (Lei n. 11.705/2008): exageros, equívocos e abusos das operações policiais. Revista IOB de Direito Penal e Processual Penal. Porto Alegre, v. 9, n. 51, ago./set. 2008, p. 208).

132 Nesse sentido, aceitando como prova tão-somente o exame clínico, o TJSC (2a Câmara, Apelação Criminal n. 3, Seara SC). Luiz Flávio Gomes faz profunda crítica a essa decisão, pois, dispensando a prova de quantificação do álcool por litro de sangue, vem condenando acusados, sem que esteja provado tal requisito típico. (GOMES, Luiz Flávio. Embriaguez ao volante (artigo 306 do CTB): um erro atrás do outro. Revista Magister de Direito Penal e Processual Penal. Porto Alegre, v. 6, n. 32, , out/nov. 2009. p. 28).

133 Essa crítica é mencionada por Luiz Flávio Gomes em outros artigos, como em "Embriaguez ao Volante: (Artigo 306 do CTB): Um erro atrás do outro": "Porque só existem duas formas de se 
Outra interpretação seria a de que a recusa a qualquer teste, seja "bafômetro", seja exame de sangue ou, ainda, exame clínico, autorizaria a aplicação da penalidade da infração administrativa ${ }^{134}$.

A principal crítica que se pode fazer é que pune-se o exercício de um direito constitucionalmente assegurado, qual seja, a garantia da vedação da auto-incriminação.

Outra interpretação é a de que a recusa a qualquer teste, seja "bafômetro”, seja exame de sangue ou, ainda, exame clínico, ensejaria o crime de desobediência ${ }^{135}{ }^{136}$

Uma crítica evidente a essa doutrina é que se todo suspeito tem o direito constitucional e internacional (visto que reconhecido em tratados internacionais) de não produzir prova contra si mesmo, não está obrigado a fazer exame de sangue ou soprar bafômetro. Sua recusa é, portanto, exercício de um direito, e quem exerce um direito comete ato lícito, e quem comete ato lícito, não comete crime. Seria, desse modo, inconstitucional a interpretação em questão.

comprovar a quantidade de álcool no sangue: exame de sangue ou bafômetro. Aliás, o bafômetro (etilômetro), a rigor, não mede a quantidade de álcool no sangue, sim, ele mede a quantidade de álcool por litro de ar. Por força do Decreto n. 6.488, que regulamentou o art. 306 do CTB, estabeleceu-se a equivalência. Seis decigramas por litro sangue (exame de sangue) correspondem a três décimos de miligrama por litro de ar (exame pelo etilometro ou bafômetro).

Ocorre que ambos exigem uma postura ativa do suspeito e ninguém é obrigado a fazer prova contra si mesmo (por força do princípio constitucional da não autoincriminação)”. (GOMES, Luiz Flávio. Embriaguez ao volante (artigo 306 do CTB): um erro atrás do outro. Revista Magister de Direito Penal e Processual Penal. Porto Alegre, v. 6, n. 32, out/nov. 2009, p. 27/28).

134 Entendimento encampado no STJ, AgRg no RHC 25.118-MG, Quinta Turma, Rel Min. Og Fernandes, j. 09.06.2009.

135 “Art. 330 - Desobedecer a ordem legal de funcionário público:

Pena - detenção, de quinze dias a seis meses, e multa”.

136 AGU (Parecer de 20.07.2009). Luiz Flávio Gomes elogia a Instrução Normativa n. 03/09 da PRF, por não ter acolhido este entendimento. Além disso, Luiz Flávio Gomes informa que há proposta de lei para endurecer a Lei Seca, segundo a qual a recusa ao bafômetro passaria a ser indício suficiente para a prisão do suspeito. (GOMES, Luiz Flávio. Embriaguez ao volante (artigo 306 do CTB): um erro atrás do outro. Revista Magister de Direito Penal e Processual Penal. Porto Alegre, v. 6, n. 32, out/nov. 2009, p. 28). 
Há, ainda, uma interpretação que, embora não seja divergente das demais, merece tratamento em separado. A referida interpretação vem sendo feita quanto aos fatos ocorridos antes da entrada em vigor da Lei 11.705/2008. É, de certa forma, decorrência de uma interpretação literal do dispositivo. Segundo esse entendimento, a nova redação do crime do art. 306, CTB é mais benéfica do que a anterior, devendo retroagir, conforme dispõe o artigo $5^{\circ}$, XL da Constituição Federal. Isso porque, atualmente, exige-se prova técnica que forneça, com exatidão, a quantidade de álcool no organismo do indivíduo. Como conseqüência, não pode persistir a persecução penal caso não haja, nos autos, prova da concentração de álcool no sangue do imputado ${ }^{137}$. Renato Marcão dispõe que:

Diante de tal quadro, as investigações criminais em andamento relacionadas com o delito de embriaguez ao volante e os processos penais em curso, onde não se fez prova técnica, ou onde, ainda que feita, não se apurou presença de concentração de álcool por litro de sangue igual ou superior a 6 (seis) decigramas por litro de sangue, estão fadadas ao insucesso.

Os inquéritos policiais em que não se produziu referida prova não poderão resultar em ação penal; as ações penais em curso, sob tais condições, não poderão ensejar condenação. ${ }^{138}$.

Por fim, merece especial consideração a opinião de Luiz Flávio Gomes de que o legislador, com a louvável intenção de ser rigoroso com os motoristas alcoolizados, acabou por gerar a impunidade de muitos deles.

Isso porque, em virtude da garantia de não auto-incriminação, o motorista surpreendido pode recusar-se a realizar os testes de "bafômetro" e exame de sangue. Sem eles, não se tem a taxa de alcoolemia; sem essa taxa, não se pode confirmar a elementar do tipo consistente em circular com concentração de álcool no sangue superior a 6 (seis) decigramas; ausente a

137 TJRJ, Apelação n. 0003410-22.2005.8.19.0023 (2009.050.01423), Relatora: Des.. Márcia Perrini Bodart, Órgão Julgador: Sétima Câmara Criminal, Julgamento: 12/05/2009.

138 MARCÃO, Renato. Crimes de Trânsito (anotações e interpretação jurisprudencial da parte criminal da Lei n. 9.503, de 23-9-1997). São Paulo, Saraiva, 2009, p. 165/166. 
referida elementar, não se pode considerar típica a conduta, devendo ser o imputado absolvido. Só seriam, assim, processados e eventualmente condenados aqueles que se submetessem espontaneamente aos exames de alcoolemia acima referidos.

Nesse sentido, Luiz Flávio Gomes vê, como única solução possível, a alteração do texto legal pelo legislador ${ }^{139}$, posição essa a que nos filiamos, conforme será mais bem exposto quando da conclusão do presente trabalho.

139 GOMES, Luiz Flávio. Embriaguez ao volante (artigo 306 do CTB): um erro atrás do outro. Revista Magister de Direito Penal e Processual Penal. Porto Alegre, v. 6, n. 32, out/nov. 2009, 


\section{Conclusão}

A era da globalização influenciou imensamente o Direito Penal, fazendo com que este passasse por uma série de transformações. Isso porque é marcada não só pelo surgimento de diversos bens jurídicos, principalmente de natureza supraindividual, como também por uma sensação geral de insegurança.

Com isso, há uma demanda pelo reforço da boa ordem da sociedade, papel esse que deveria ser desempenhado por diversos ramos do Direito. Entretanto, o descrédito das demais instâncias de proteção pressionou para que toda uma nova gama de tutelas fosse exercida pelo Direito Penal. Nesse sentido, o Direito Penal vivencia um processo de expansão.

Pode-se dizer que um dos aspectos dessa expansão é que o Direito Penal passou a exercer a função de direito voltado para a gestão de riscos gerais inerentes à sociedade atual, tipicamente exercida pelo Direito Administrativo. Ganhou, assim, progressivamente, características deste ramo do Direito, ocorrendo uma mudança de paradigma, que é o Direito Penal “administrativizado".

O Direito Penal “administrativizado” é marcado pela flexibilização de princípios penais garantidos pelo Estado democrático de direito, principalmente os princípios da exclusiva proteção de bens jurídicos, da ofensividade, da culpabilidade, da proporcionalidade e da subsidiariedade.

Em suma, o Direito Penal da sociedade da globalização assumiu a forma de racionalizar própria do Direito Administrativo sancionador, se convertendo em direito de gestão ordinária de grandes problemas sociais.. Nessa medida, vem sofrendo um processo de banalização, sendo usado como instrumento de execução de políticas da Administração Pública ou de gestão dos riscos sistêmicos. Por isso, o ilícito penal confunde-se cada vez mais com 
ilícito administrativo, e o Direito Penal com o Direito Administrativo sancionador.

Pois bem. Esse novo paradigma do Direito Penal teve reflexos na recente modificação do crime de embriaguez ao volante (artigo 306 do Código de Trânsito Brasileiro), promovida pela Lei 11.705/2008.

A referida alteração do tipo foi recebida com ressalvas pela doutrina e, principalmente, com controvertida aplicação pelos tribunais.

É que o legislador, no referido dispositivo legal, tipificou a conduta de conduzir veículo automotor, na via pública, estando com concentração de álcool por litro de sangue igual ou superior a 6 (seis) decigramas e a conduta de conduzir veículo automotor, na via pública, sob a influência de qualquer outra substância psicoativa que determine dependência.

Assim, por uma interpretação literal do dispositivo, o crime de dirigir alcoolizado seria de perigo abstrato, presumindo-se a lesividade da conduta por um critério meramente estatístico, que determinaria o grau de concentração de álcool no sangue a partir da qual se consideraria a direção necessariamente perigosa. Adotando-se essa interpretação, o crime de embriaguez ao volante não passaria de um reforço das normas administrativas sancionadoras.

Entretanto, em respeito aos princípios penais constitucionais, não se pode admitir delitos com essa estrutura. Deve ser feita, dessa forma, uma interpretação conforme a Constituição, devendo-se exigir que se demonstre a lesividade concreta da conduta, em cada caso. Entendemos, assim, que o crime de embriaguez ao volante é de perigo concreto, sob pena de ser inconstitucional. 
Por isso, não basta ter uma determinada concentração de álcool no sangue, porque seus efeitos variam de pessoa para pessoa, e o grau de periculosidade da conduta depende das circunstâncias do fato como um todo.

Nesse diapasão, consideramos acertada a corrente doutrinária que entende que "estar sob influência" de álcool é elementar do tipo penal, embora não esteja expressa. Adotamos, como fundamento dessa posição, os argumentos da exigência de lesividade concretamente demonstrada; da impossibilidade da infração administrativa, que é o "menos", exigir a influência, e a penal, que é o "mais", não fazê-lo; além da interpretação sistemática dos dispositivos legais do Código de Trânsito Brasileiro.

Frisamos, igualmente, que a referida influência de álcool tem de levar o motorista a dirigir de forma anormal, arriscada, como, por exemplo, em ziguezague, subindo na calçada ou em velocidade excessiva, etc. Sem que haja uma direção anormal, o crime não se configura.

O que se observa, portanto, é que a estrutura do crime de embriaguez ao volante elaborada pelo legislador é extremamente criticável, por violar diversos princípios penais constitucionalmente assegurados, refletindo o que ocorre neste paradigma de “administrativização” do Direito Penal.

Mas não é só. O fato de o tipo penal em questão determinar uma precisa concentração de álcool no sangue para que se configure o crime é também problemático. Isso porque os únicos exames técnicos, capazes de fornecer esse dado com precisão são o exame de sangue e o etilômetro.

Ocorre que os referidos testes de alcoolemia dependem da cooperação do acusado para sua realização, o que envolve diretamente o princípio nemo tenetur se detegere, inserido no ordenamento jurídico brasileiro por constar do artigo 5º LXIII da Constituição Federal; pela adoção de tratados internacionais 
de direitos humanos, com status constitucional; e por algumas normas infraconstitucionais, de recente alteração.

De acordo com o referido princípio, os indivíduos têm o direito de não se auto-incriminar, e disso decorrem: a possibilidade de recusa, não só por parte do preso, mas também do acusado, ou de qualquer pessoa, em colaborar com a persecução penal, sem que disso decorra qualquer conseqüência negativa; a obrigatoriedade de advertência desse direito pela autoridade; e a nulidade das provas feitas com a sua violação.

Devido a isso, o condutor surpreendido tem o direito de recusar-se a realizar o exame de sangue e o teste do "bafômetro", sem que daí possam decorrer quaisquer consequiências negativas, tendo em vista que tal recusa se trata de direito constitucionalmente garantido.

Em vista disso, em que pese haver parte importante da doutrina que defenda o contrário, consideramos inconstitucional a imposição de qualquer sanção a essa recusa, seja a imputação do crime de desobediência, seja a aplicação de penalidades administrativas. Por isso, não cabe interpretar literalmente o artigo 277, § $3^{\circ}$, CTB, devendo somente ser aplicado em caso de recusa ao exame clínico.

Portanto, observa-se que o tipo penal foi construído de forma que o crime somente se configure se o acusado aceitar se submeter aos mencionados testes de alcoolemia, colaborando com a persecução penal.

Recusando-se a tais exames, nenhuma sanção poderá lhe ser imposta e, mais ainda, frustra-se a persecução penal, tendo em vista que somente exames técnicos que dependem da colaboração do acusado são aptos a provar a existência da elementar do tipo penal "concentração de álcool por litro de sangue igual ou superior a 6 (seis) decigramas". 
É por isso, aliás, que se tem gerado a impunidade em muitos casos de pessoas acusadas ou condenadas pelo crime de embriaguez ao volante antes da Lei 11.705/2008. Isso porque, em grande parte desses processos, não se havia aferido a exata concentração de álcool no sangue e, como a referida lei instituiu essa exigência, acabou por ser mais benéfica e retroagir nesses casos, ocorrendo a absolvição por não se ter sido provada uma elementar típica.

Diante de tantas polêmicas, vimos que houve intenso debate doutrinário e divergente aplicação da lei pelos tribunais, de forma que surgiram múltiplas interpretações quanto ao crime de embriaguez ao volante.

Embora sejam todas merecedoras de cuidadosa apreciação, acreditamos que a atual geometria delitiva do artigo 306 do Código de Trânsito Brasileiro oferece obstáculos intransponíveis a sua correta aplicação. Acabará, em verdade, resultando na condenação de indivíduos que nenhum risco concreto ofereceram à segurança viária e, por outro lado, na impunidade daqueles que colocaram em verdadeiro perigo o tráfego de veículos.

Por isso, embora louvável a iniciativa do legislador de tornar mais rigorosa a legislação com relação à embriaguez ao volante, dado o número de mortes ocasionadas nas ruas e estradas do país, isso não o autoriza a adotar formas inconstitucionais de fazê-lo.

Nesse sentido, consideramos acertada a decisão de aumentar o rigor em relação à infração administrativa e, principalmente, de aumentar a fiscalização. Porém, acreditamos ser equivocada a mudança feita na legislação quanto à infração penal, sugerindo que se modifique a lei para criminalizar a embriaguez ao volante nos moldes em que era feito anteriormente ("conduzir veículo automotor, na via pública, sob a influência de álcool ou substância de efeitos análogos, expondo a dano potencial a incolumidade de outrem”) 
Essa seria uma forma de punir a embriaguez ao volante sem que seja vinculada à determinada concentração de álcool por litro de sangue, o que resolveria a polêmica em torno da obrigatoriedade do "bafômetro", já que a prova testemunhal e o exame clínico seriam alternativas igualmente idôneas para demonstrar a ocorrência do crime.

Não haveria dúvidas, também, de que se trataria de crime de perigo concreto, de forma que, assim, seriam devidamente respeitados os princípios penais constitucionalmente assegurados. 


\section{Bibliografia}

ALCÁCER GUIRAO, Rafael. Embriaguez, temeridad y peligro para la seguridad del tráfico: consideraciones en torno a la reforma del delito de conducción temeraria. La Ley Penal: revista de derecho penal, procesal y penitenciario. Madrid, v. 1, n. 10, p.5-22, Nov. 2004.

AMARAL, Thiago Bottino do. A doutrina brasileira do direito ao silêncio: O STF e a conformação do sistema processual penal constitucional. In: PRADO, Geraldo (Org.); MALAN, Diogo (Org.). Processo Penal e Democracia: Estudos em Homenagem aos 20 Anos da Constituição da República de 1988. Rio de Janeiro: Lúmen Júris, 2009, 598 p.

AMARAL, Thiago Bottino do. O direito ao silêncio na jurisprudência do STF. Rio de Janeiro: Campus/Elsevier, 2009.

AZEVEDO, David Teixeira de. O interrogatório do réu e o direito ao silêncio. Revista dos Tribunais. São Paulo, v.81, n.682, p.285-95, ago. 1992.

BARATTA, Alessandro. Funções instrumentais e simbólicas do direito penal: lineamentos de uma teoria do bem jurídico. Revista Brasileira de Ciências Criminais. São Paulo, v. 2, n. 5, p.5-24, jan./mar. 1994.

BECHARA, Ana Elisa Liberatore S. Delitos de acumulação e racionalidade da intervenção penal. Boletim IBCCRIM. São Paulo: IBCCRIM, ano 17, n. 208, p. 03-05, mar., 2010.

BEDÊ JÚNIOR, Américo; SENNA, Gustavo. Princípios do processo penal. São Paulo: Editora Revista dos Tribunais, 2009. 388p.

BEJERANO GUERRA, Fernando. Los efectos de las reformas penales en el delito de conducción bajo la influencia de bebidas alcohólicas. La Ley Penal: 
revista de derecho penal, procesal y penitenciario. Madrid, v. 1, n. 10, p.23-38, Nov. 2004.

CALLEGARI, Andre Luis. A inconstitucionalidade do teste de alcoolemia e o novo Código de Trânsito. Revista dos Tribunais. São Paulo, v.87, n.757, p.42631, nov. 1998.

CALLEGARI, André Luís. A inconstitucionalidade do teste de alcoolemia no código de trânsito brasileiro. In: CALLEGARI, André Luís. Imputação objetiva: lavagem de dinheiro e outros temas de direito penal. Porto Alegre: Livraria do Advogado, 2001. 208 p.

CASTRO, Cássio Benvenutti de. Retroatividade secundum eventum probationis do novo art. 306, do CTB. Revista Ibero-Americana de Ciências Penais. Porto Alegre, v. 8, n. 16, p.97-114, jul./dez. 2008.

DIAS NETO, Theodomiro. -- $O$ direito ao silencio nos direitos alemão $e$ norte-americano. Revista Brasileira de Ciências Criminais. São Paulo, v.5, n.19, p.179-204, jul./set. 1997.

DIAS, Augusto Silva. What if everybody did it? Sobre a (in)capacidade de ressonância do direito penal à figura da acumulação. Revista Portuguesa de Ciência Criminal. Coimbra, ano 13, p. 303-345, jul./set. 2003.

FEIJÓO SÁNCHEZ, Bernardo J. Cuestiones basicas de los delitos de peligro abstracto y concreto en relacion con el transito. Revista da AJURIS. Porto Alegre, v.26, n.78, p.290-324, jun. 2000.

FERNANDES, Antonio Scarance. Processo penal constitucional. São Paulo: Editora Revista dos Tribunais, 1999. 317p.

GOMES, Luiz Flávio \& YACOBUCCI, Guillermo. As grandes 
transformações do direito penal tradicional.tradução da $2^{a}$ parte Lauren Paoletti Stefanini. São Paulo: Editora revista dos Tribunais, 2005.

GOMES, Luiz Flávio e BIANCHINI, Alice. O direito penal na era da globalização: hipertrofia irracional (caos normativo), instrumentalização distorciante... São Paulo: Editora revista dos Tribunais, 2002, 162 p.

GOMES, Luiz Flávio et all.. Comentários às Reformas do Código de Processo Penal e da Lei de Trânsito. São Paulo: Editora Revista dos Tribunais, 2008.

GOMES, Luiz Flávio. Bafômetro: é obrigatório?. Revista Magister de Direito Penal e Processual Penal. Porto Alegre, v. 6, n. 31, p.11-14, ago./set. 2009.

GOMES, Luiz Flávio. Embriaguez ao volante (artigo 306 do CTB): um erro atrás do outro. Revista Magister de Direito Penal e Processual Penal. Porto Alegre, v. 6, n. 32, p.27-29, out/nov. 2009.

GOMES, Luiz Flávio. Embriaguez ao volante: reforma do Código de Trânsito (lei $n^{\circ}$ 11.705/2008). Revista Magister de Direito Penal e Processual Penal, Porto Alegre, v. 4, n. 24, p.94-101, jun./jul. 2008.

GOMES, Luiz Flávio. Lei Seca (Lei n. 11.705/2008): exageros, equívocos e abusos das operações policiais. Revista IOB de Direito Penal e Processual Penal. Porto Alegre, v. 9, n. 51, p.208-209, ago./set. 2008.

GOMES, Luiz Flavio. Princípio da ofensividade no direito penal: não há crime sem lesão ou perigo concreto de lesão ao bem jurídico (nullum crimen sine iniuria), funções político-criminal e dogmático-interpretativa, o princípio da ofensividade como limite do ius puniendi, o princípio da ofensividade como limite do ius poenale, São Paulo: Editora Revista dos Tribunais, 2002, p. 43, $116 \mathrm{p}$. 
GOMES, Luiz Flávio. Reforma do Código de Trânsito (Lei $n^{\circ}$ 11.705/2008): novo delito de embriaguez ao volante. IOB - repertório de jurisprudência: civil, processual, penal e comercial. São Paulo, v.3, n.15, p.513-2, ago. 2008.

GRINOVER, Ada Pellegrini; FERNANDES, Antonio Scarance; GOMES FILHO, Antonio Magalhães. As nulidades no processo penal. $10^{\mathrm{a}}$ Ed. São Paulo: Editora Revista dos Tribunais, 2007. 369p.

GUIMARÃES, Isaac Sabbá. Exame de alcoolemia: sua validade como prova no processo penal. Revista Brasileira de Ciências Criminais, São Paulo, n. 33, p.121-132, jan./mar. 2001.

JESUS, Damásio de. Embriaguez ao volante: a alteração do artigo 165 do Código de Trânsito e o nível de tolerância na ingestão de substância alcoólica ou de efeito análogo (taxa de alcoolemia). Revista Magister de Direito Penal e Processual Penal. Porto Alegre. v.2. n.11. p.15-7. abr./maio. 2006.

JESUS, Damásio de. Embriaguez ao volante: a alteração do artigo 165 do Código de Trânsito e o nível de tolerância na ingestão de substância alcoólica ou de efeito análogo (taxa de alcoolemia). Revista Magister de Direito Penal e Processual Penal. Porto Alegre, v.2, n.11, p.15-7, abr./maio. 2006.

JESUS, Damásio de. Embriaguez ao volante: notas à Lei $n^{\circ}$ 11.705/2008. Revista IOB de Direito Penal e Processual Penal. Porto Alegre. v.9. n.52. p.327. out./nov. 2008.

JESUS, Damásio Evangelista de. Limites à prova da embriaguez ao volante: a questão da obrigatoriedade do teste do bafômetro. Revista Síntese de Direito Penal e Processual Penal. Porto Alegre, v.5, n.28, p.27-34, out./nov. 2004.

MARCÃO, Renato. Crimes de Trânsito (anotações e interpretação 
jurisprudencial da parte criminal da Lei n. 9.503, de 23-9-1997). São Paulo: Saraiva, 2009.

MIRABETE, Julio Fabbrini. Manual de direito penal, 22 ed., São Paulo: Atlas, 2005, 457p.

MORILLAS FERNÁNDEZ, David Lorenzo. La conducción de vehículos a motor bajo la influencia del alcohol. Cuadernos de Política Criminal, Madrid, n. 87, p.65-92, 2005.

MOURA, Maria Thereza Rocha de Assis et all. Direito ao silencio no interrogatório. Revista Brasileira de Ciencias Criminais. Sao Paulo, v.2, n.6, p.133-47, abr./jun. 1994.

NUCCI, Guilherme de Souza. Provas no processo penal. São Paulo: Editora Revista dos Tribunais, 2009.

PELUSO, Vinicius de Toledo Piza. O crime de embriaguez ao volante e o "bafômetro": algumas observações. Boletim IBCCRIM. São Paulo, v. 16, n. 189, p.16, ago/2008.

QUEIJO, Maria Elizabeth. O direito de não produzir prova contra si mesmo (o princípio Nemo tenetur se detegere e suas decorrências no processo penal). São Paulo: Saraiva, 2003, 435 p.

REALE JÚNIOR, Miguel. Crime de embriaguez ao volante. Revista de Direito Penal. Rio de Janeiro, n. 6, p.81-89, abr./jun. 1972.

SILVA SÁNCHEZ, Jesús-Maria. A expansão do Direito Penal: aspectos da política criminal nas sociedades pós-industriais. São Paulo: Editora Revista dos Tribunais, 2002, 154 p. 
SILVA SÁNCHEZ, Jesús-Maria. Consideraciones sobre el delito del Art. 340 Bis a) $1^{\circ} \mathrm{CP}$ (conduccion bajo la influencia de bebidas alcoholicas, drogas toxicas). Revista Juridica de Catalunya. Baja California Norte, v.92, n.1, p.2557, 1993.

SILVA, Ângelo Roberto Ilha da. Dos crimes de perigo abstrato em face da Constituição. São Paulo: Editora Revista dos Tribunais, 2003.

TUCCI, Rogério Lauria. Direitos e garantias individuais no processo penal brasileiro. 2a Ed. São Paulo: Editora Revista dos Tribunais, 2004. 444p.

STJ, Habeas Corpus 155069, Relatora: Min. Laurita Vaz, Órgão Julgador: Quinta Turma, Brasília, publicação: DJe 26/04/2010

STJ, AgRg no RHC 25.118-MG, Quinta Turma, Rel Min. Og Fernandes, Brasília, julgamento em 09.06.2009.

TJRJ, Habeas Corpus n. 0063279-43.2009.8.19.0000, Rel. Des. Antonio Carlos Amado, Sexta Câmara Criminal, Rio de Janeiro, julgamento em 26/01/2010.

TJRJ, apelação n. 0000602-94.2008.8.19.0037 (2009.050.04719), Rel. Des. Eunice Ferreira Caldas, Sexta Câmara Criminal, Rio de Janeiro, julgamento em 17/11/2009.

TJRJ, Habeas Corpus n. 0010274-72.2010.8.19.0000, Relator: Des. Marcus Quaresma, Órgão julgador: Oitava Câmara Criminal, Rio de Janeiro, julgamento em 24/03/2010.

TJRJ, Habeas Corpus n. 0061086-55.2009.0000, Relatora: Des. Rosita Oliveira Netto, Órgão Julgador: Sexta Câmara Criminal, Rio de Janeiro, publicação em 16/04/2010. 
TJRJ, Recurso em sentido estrito n. 0199642-34.2009.8.19.0001 (2009.051.00728), Relatora: Des. M.SANDRA KAYAT DIREITO, Órgão Julgador: Quarta Câmara Criminal, Rio de Janeiro, julgamento em 12/01/2010.

TJRJ, Apelação n. 0003410-22.2005.8.19.0023 (2009.050.01423), Relatora: Des.. Márcia Perrini Bodart, Órgão Julgador: Sétima Câmara Criminal, Julgamento: 12/05/2009. 